Federal Reserve Bank of Minneapolis

Research Department Staff Report 309

Revised May 2005

\title{
Taxes, Regulations, and the Value of U.S. and U.K. Corporations*
}

\author{
Ellen R. McGrattan
}

Federal Reserve Bank of Minneapolis

and University of Minnesota

\section{Edward C. Prescott}

Federal Reserve Bank of Minneapolis

and Arizona State University

\begin{abstract}
We derive the quantitative implications of growth theory for U.S. corporate equity plus net debt over the period 1960-2001. There were large secular movements in corporate equity values relative to GDP, with dramatic declines in the 1970s and dramatic increases starting in the 1980s and continuing throughout the 1990s. During the same period, there was little change in the capital-output ratio or earnings share of output. We ask specifically whether the theory accounts for these observations. We find that it does, with the critical factor being changes in the U.S. tax and regulatory system. We find that the theory also accounts for the even larger movements in U.K. equity values relative to GDP in this period.
\end{abstract}

*Corresponding author: Prescott, Research Department, 90 Hennepin Avenue, P.O. Box 291, Minneapolis, MN, 55480-0291, edward.prescott@asu.edu. Data, codes, and a technical appendix are available for this paper at http://www.minneapolisfed.org/research/sr/sr309.html. We thank Andy Abel, Alan Auerbach, Bob Hall, Ravi Jagannathan, Urban Jermann, Narayana Kocherlakota, Lee Ohanian, Jim Poterba, Kathy Rolfe, Bob Shiller, four anonymous referees, and the editor for their comments. We thank Martin Weale and Shane Duffield for their help with U.K. data. We also thank the National Science Foundation for financial support. The views expressed herein are those of the authors and not necessarily those of the Federal Reserve Bank of Minneapolis or the Federal Reserve System. 


\section{Introduction}

The value of the U.S. stock market relative to gross domestic product (GDP) has varied and varied a lot. (See Figure $1 .^{1}$ ) In the mid-1970s, the value of corporate equity relative to GDP fell to half of the 1960s average. Starting in the mid-1980s, corporate valuations began to rise. By 2000, the value of corporate equity relative to GDP was nearly twice the 1960s average. After 2000, equity values fell relative to GDP but remained high relative to the 1960s levels. Stock market analysts view these dramatic movements as puzzling because there has not been significant change relative to GDP in three key market fundamentals: corporate capital stock, after-tax corporate earnings, and corporate net debt.

There is another factor that strongly affects the value of corporate equity, however, and this factor has changed a lot since 1960: a country's tax and regulatory system. In this study, we use growth theory to derive the quantitative implications of U.S. tax and regulatory changes for U.S. corporate valuations, capital-output ratios, and corporate earnings' share of product. In particular, we derive a formula for the value of corporate equity plus net debt and evaluate it using Bureau of Economic Analysis (BEA) data for the capital stocks and Internal Revenue Service (IRS) data for tax rates. We focus on low-frequency, or secular, movements in aggregate values, all in relation to the movements in GDP. The growth model was developed to account for such statistics. We ask specifically whether the theory accounts for the dramatic secular changes in U.S. corporate valuations and the small changes in U.S. capital-output ratios and earnings shares. We find that it does.

In particular, we find that the large decline in the effective marginal tax rate on U.S. corporate distributions accounts for the high value of equities in the late 1990s relative to the 1960s. There are two reasons for the big decline in this tax rate. First, there were reductions in marginal income tax rates, with the largest changes beginning in the early 1980s. Second, and more importantly, there were changes in the legal and regulatory system that led to a dramatic increase in the share of corporate equity held by entities that pay no tax on dividend or capital gains income. The percentage of corporate equity held by these entities - namely, pension funds, individual retirement accounts, and nonprofit organizations-increased from 4 percent in 1960 to 51 percent in 2000 .

The crucial prediction of the theory we use is that the effective marginal tax rate on distributions affects the value of the stock market, through the price of tangible and intangible capital, 
Figure 1. Value of U.S. Corporations, 1960-2001

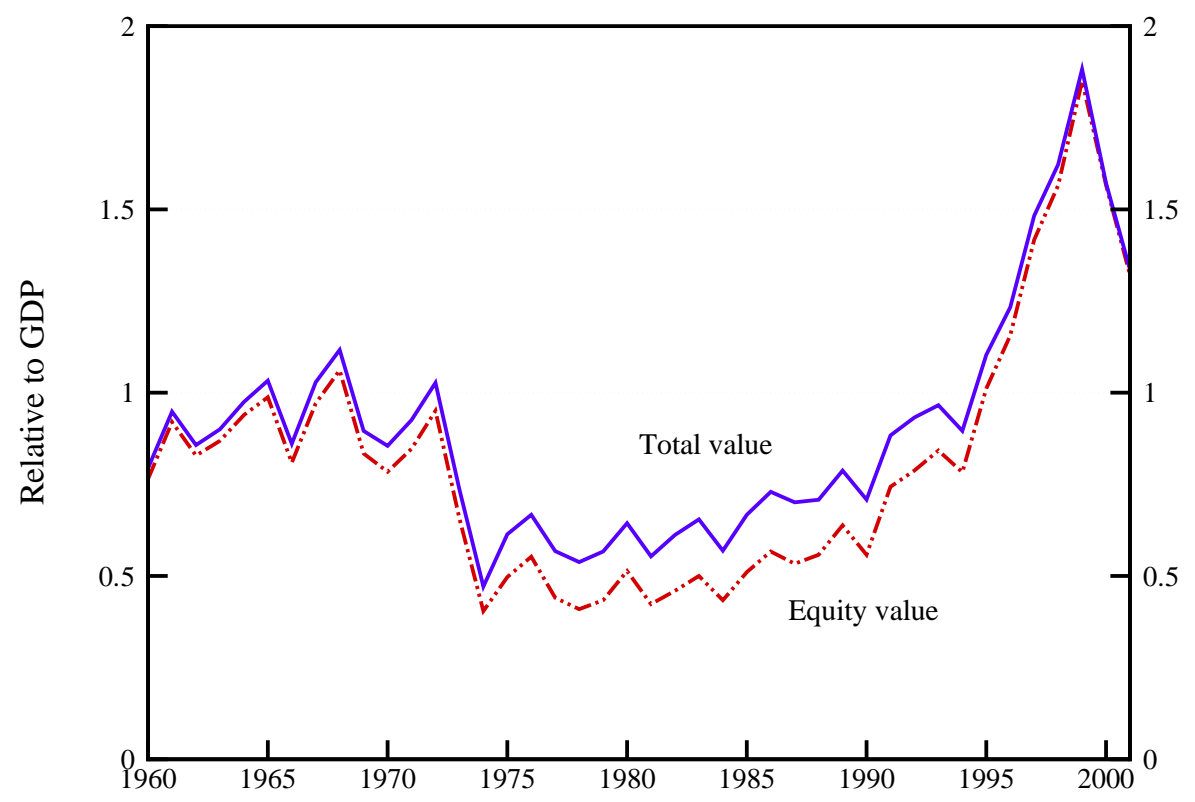

but does not affect the cost of reproducible capital. The principal reason that the total value of corporations nearly doubled relative to GDP between 1960 and 2000 was not that the cost of reproducible capital relative to GDP increased, as the ratio changed hardly at all. Rather it was that the effective marginal tax rate on corporate distributions fell by more than a factor of two.

There was an extended period from 1975 through 1985 when the value of corporate equity was about half of the 1960s average. One contributing factor to these lower equity values was the substitution of debt-financing for equity-financing. This swap occurred as personal income tax rates fell below corporate income tax rates. Another contributing factor was a change in tax policy that subsidized new capital. Increased use of investment tax credits and accelerated depreciation allowances led to a fall in the price of capital and thus a fall in the value of equity relative to corporate capital.

Stock market values began to rise in the mid-1980s because most capital subsidies were eliminated by the Tax Reform Act (TRA) of 1986, individual income tax rates were lowered, and tax-deferred accounts were increasingly used. The adjustment to a higher value-output ratio was gradual, taking about 15 years. We find that constraints on individuals shifting savings from nonretirement accounts to retirement accounts result in a long adjustment, with a 15-year transition 
being reasonable.

The United Kingdom is another country that experienced large secular movements in corporate equity values over the post-World War II period, and its movements were even larger than those in the United States. We find that here, as in the United States, changes in tax and regulatory policy account for much of the low-frequency variation in corporate valuations during the 1960-2001 period. In the United Kingdom, there were generous subsidies to investment in the 1970s that were significantly larger than those in the United States. Shareholders in the United Kingdom saw their effective tax rates on distributions fall sooner and more dramatically than rates in the United States. We find that these changes account for the pattern and magnitudes of change of U.K. corporate valuations. As theory predicts, the United Kingdom experienced lower equity values in the 1970s and an earlier and larger increase in the 1980s and 1990s than we observed in the United States. As did the United States, the United Kingdom had regulations on corporate distributions and retirement investments that implied a long transition period for the rise in equity values.

The literature that looks at movements in equity prices is vast, but there is some work that, like ours, considers the decline in values in the 1970s and the rise in values in the 1980s and 1990s. Feldstein (1980) shows that a permanent inflation can have the effect of lowering the price of equities if tax rules are like those in place in the United States during the 1970s. We too allow for inflationary effects but find the consequences to be small. Another factor that can have an adverse effect on equity values is the arrival of information technology (IT) which signals an end to old technologies and a decline in their values. Studies of the IT revolution include those of Greenwood and Jovanovic (1999), Hobijn and Jovanovic (2001), and Laitner and Stolyarov (2003). Recent work by Peralta-Alva (2003) considers the quantitative implications of these technology-driven theories and finds that a large and persistent decline in the stock market value is necessarily accompanied by large and counterfactual changes in key macroeconomic aggregates.

Other related work offers explanations for the rise in equity values during the 1990s. Shiller (2000) suggests that the high value of the U.S. stock market reflects "irrational exuberance" among investors. $^{2}$ He provides no theoretical justification, however, for the claim that the stock market in 2000 was overvalued. Hall (2001) attributes the rise in the market value of equity to higher intangible investment during the 1990s. However, Hall's value of intangible capital is residually determined as the difference between the market value of corporate equity and the value of tangible 
capital and, therefore, accounts for the run-up in prices by construction. Heaton and Lucas (1999) quantify the contribution of increased participation and reduced dividend volatility (proxying for diversification) for stock values and returns. They find that observed changes in participation are too small to generate a large change in stock values. Additionally, reducing dividend volatility does imply some increase in the price-dividend ratio, but Heaton and Lucas provide no evidence that such a change is consistent with observations. Abel (2003) explores the idea that higher saving by baby boomers leads to an increase in the market value relative to GDP. Quantitatively, this explanation has two difficulties. First, Abel's model cannot generate a value to GDP ratio above 1 , when in fact the ratio was 1.6 in 2000 . Second, historical variations in investment-output ratios are simply too small to generate large variations in the model's prediction for the price of capital.

In Section 2, we present a simple growth model and use it to derive the key relation between the market value of corporations and the value of productive corporate capital. Then, in Section 3, we relate the result to the U.S. economy. To determine the quantitative predictions of the theory for U.S. observations, we extend the simple version of the growth model to include features of the U.S. tax and regulatory codes, and we display the model's predictions against the actual U.S. values for measures of corporate value. In Section 4, we use the theory to make predictions for valuations of U.K. corporations, and compare the U.S. and U.K. results. In Section 5, we demonstrate that adjustments in corporate valuations can take a long time after tax reforms if individuals face constraints on reallocating their asset holdings. In Section 6 , we summarize our findings and discuss issues for future research.

\section{Theory}

In this section, we present a simple version of the growth model and use it to highlight the main equilibrium relation that we use to estimate the value of the stock market. ${ }^{3}$ This relation equates the market value of the corporations to the value of the productive capital in the corporate sector.

Because the relation does not change when we extend the model to incorporate details of the U.S. and U.K. economies, we start with the simplest structure possible. The model economy has a corporate sector, a household sector, and a simple tax system with taxes on corporate income and distributions and subsidies to capital investment. With this simple framework, we have all that we need to derive the key equilibrium relation. We show how this relation can be interpreted in light 
of alternative tax and regulatory policies. This will be helpful when we look at specific tax and regulatory changes and their effects on the value-output and capital-output ratios in the United States and the United Kingdom.

Here and later we take as exogenous corporations' financing decisions. The theory we use provides a prediction for the total value of corporations, equity plus net debt. To keep the analysis simple, we model the corporation as issuing only equity, but it is straightforward to allow for debt and to relate the sum of the market values of debt and equity to the value of productive capital. ${ }^{4}$

We also abstract from uncertainty in pricing equity throughout because our main results are unchanged by including it.

\section{A. The Equilibrium Relation for the Value of Corporations}

Consider the following model economy. The economy is inhabited by infinitely lived households with preferences ordered by

$$
\sum_{t=0}^{\infty} \beta^{t} U\left(c_{t}, n_{t}\right)
$$

where $t$ indexes time, $c$ is per-capita consumption, and $n$ is labor supply. ${ }^{5}$

We use $p_{t}$ to denote the household's price of period $t$ consumption and $i_{t}=p_{t} / p_{t+1}-1$ to denote the after-tax interest rate. Each household chooses sequences of consumption and labor to maximize utility subject to its budget constraint,

$$
\sum_{t} p_{t}\left\{c_{t}+v_{t}\left(s_{t+1}-s_{t}\right)\right\} \leq \sum_{t} p_{t}\left\{\left(1-\tau_{d i s t}\right) d_{t} s_{t}+w_{t} n_{t}+\psi_{t}\right\}
$$

This constraint says that the present discounted value of expenditures must be less than or equal to the present discounted value of after-tax income. Expenditures of the household are consumption

and purchases of shares in stocks, $v_{t}\left(s_{t+1}-s_{t}\right)$, where $s_{t}$ is the number of shares held at the beginning of period $t$ and $v_{t}$ is the price per share. Receipts of the households are corporate distributions, wages, and government transfers. We denote distributions per share by $d$, the wage rate by $w$, and government transfers by $\psi$. The households pay taxes on distributions, at a rate equal to $\tau_{d i s t}$. Later, we estimate this and other relevant tax rates for the United States and United Kingdom. 
Corporations have capital and hire labor to produce output with a constant returns-to-scale production technology, ${ }^{6}$

$$
y_{t}=f\left(k_{m, t}, k_{u, t}, z_{t} n_{t}\right)
$$

This specification assumes that corporations use both tangible assets $k_{m}$, which are measured, and intangible assets $k_{u}$, which are unmeasured. Tangible assets include structures, equipment, inventories, and land. Intangible assets include brand names, patents, and forms of organizational capital. In addition to capital, labor services $n$ are required. The technology parameters, $z_{t}$, are assumed to grow at rate $\gamma$.

Distributions to the household are equal to what corporations have after making new investments, paying wages, paying taxes, and receiving subsidies. Corporations pay taxes on income at rate $\tau_{\text {corp }}$. and receive subsidies to tangible investment at rate $\tau_{\text {subs }}$. The distributions are given by

$$
\begin{aligned}
d_{t}=f\left(k_{m, t}, k_{u, t}, z_{t} n_{t}\right)-x_{m, t}-x_{u, t}-w_{t} n_{t} \\
\quad-\tau_{\text {corp }}\left[f\left(k_{m, t}, k_{u, t}, z_{t} n_{t}\right)-\delta_{m} k_{m, t}-x_{u, t}-w_{t} n_{t}\right]+\tau_{s u b s} x_{m, t}
\end{aligned}
$$

where $x_{m}$ is new investment in measured tangible capital and $x_{u}$ is new investment in unmeasured intangible capital. Corporations can expense intangible investments, and therefore $x_{u}$ is deducted when computing taxable corporate income. They choose capital and labor to maximize the present value of distributions net of taxes paid by households on distributions:

$$
\begin{aligned}
\sum_{t=0}^{\infty} p_{t} d_{t}\left(1-\tau_{\text {dist }}\right) & \\
\text { s.t. } k_{m, t+1} & =\left(1-\delta_{m}\right) k_{m, t}+x_{m, t} \\
k_{u, t+1} & =\left(1-\delta_{u}\right) k_{u, t}+x_{u, t} .
\end{aligned}
$$

Market-clearing in this economy requires that the labor market clears; the equity market clears $\left(s_{t}=1\right)$; and the goods market clears,

$$
c_{t}+x_{m, t}+x_{u, t}=f\left(k_{m, t}, k_{u, t}, z_{t} n_{t}\right) .
$$


Three equilibrium conditions which we use subsequently are

$$
\begin{aligned}
\frac{p_{t}}{p_{t+1}} & =\frac{v_{t+1}+\left(1-\tau_{\text {dist }}\right) d_{t+1}}{v_{t}} \\
\frac{p_{t}}{p_{t+1}} & =\left[\left(1-\tau_{\text {corp }}\right)\left(f_{1}\left(k_{m, t+1}, k_{u, t+1}, z_{t+1} n_{t+1}\right)-\delta_{m}\right)+\tau_{\text {subs }} \delta_{m}\right] /\left(1-\tau_{\text {subs }}\right)+1 \\
\frac{p_{t}}{p_{t+1}} & =f_{2}\left(k_{m, t+1}, k_{u, t+1}, z_{t+1} n_{t+1}\right)-\delta_{u}+1 .
\end{aligned}
$$

These three conditions say, among other things, that the returns to stocks and the two types of capital must be equal. The different corporate tax treatment on tangible and intangible capital leads to the differences evident in expressions (10) and (11).

Proposition 1. An equilibrium relation specifying the price of corporate equity as a function of tax rates and corporate capital stocks is

$$
v_{t}=\left(1-\tau_{\text {dist }}\right)\left[\left(1-\tau_{\text {subs }}\right) k_{m, t+1}+\left(1-\tau_{\text {corp }}\right) k_{u, t+1}\right] .
$$

Proof: This follows from equation (4), conditions (9)-(11), and the fact that the wage is equal to the marginal product of labor in equilibrium.

The price in (12) is the unique equilibrium price if there are buyers and sellers, as would be true in an overlapping generations model. It is also the unique equilibrium price for this dynastic economy if the tax rate on realized capital gains is zero.

The price of tangible capital for the shareholders is $\left(1-\tau_{\text {dist }}\right)\left(1-\tau_{\text {subs }}\right)$, not 1 . The distribution tax affects this price because a dollar reinvested is not taxed, but a dollar distributed is. Similarly, a subsidy to tangible investment affects this price because it makes investing in tangibles cheaper. Absent unmeasured capital, the price of tangible capital is a measure of Tobin's $q$. This is closely related to the expression for $q$ found by others. If, for example, there is no accrual-capital gains tax, as is the case for the United States, then $q$ is the same as in much of the public finance literature. $^{7}$

The price of intangible capital is $\left(1-\tau_{\text {dist }}\right)\left(1-\tau_{\text {corp }}\right)$. The price of intangible capital depends on the corporate distribution tax in the same way and for the same reason does as the price of 
tangible capital. The price of intangible capital also depends on the corporate income tax rate because investments in intangible capital are expensed and reduce taxable corporate income.

Finally, we should note that extending the model to allow for tax rates that vary deterministically or stochastically does not change the equilibrium relation in equation (12) (except in that tax rates would be indexed by time). The relation is valid provided that investment is not zero in the model, distributions are made by corporations, and new investment is financed by retained earnings. ${ }^{8}$ As Sinn (1991) emphasizes, it is an empirical fact that most corporate equity capital is generated by retained earnings rather than new equity issues. 9

\section{B. Interpreting the Tax on Distributions}

In the U.S. tax system, capital gains are taxed upon realization. Thus, the relevant tax rate for corporate distributions (that is, $\tau_{d i s t}$ in equation (12)) is the personal income tax rate on dividend income if corporations make distributions to households by paying dividends, and it is the realized capital gains tax rate if corporations make distributions by buying back shares or liquidating operations. If a combination of the two is used, the rate will be between these two rates.

If equity is held in tax-deferred retirement accounts, then the appropriate tax on distributions in (12) is zero even if the contributions are taxed when they are withdrawn. To see why this is true, consider an individual investing one dollar in equity funds in a retirement account, which yields a per-period return of $i$. Suppose the personal tax rate is $\tau_{\text {pers }}$. The individual gives up $\left(1-\tau_{\text {pers }}\right)$

today for $\left(1-\tau_{\text {pers }}\right)(1+i)^{k} k$ periods hence. The tax is effectively a consumption tax and does not affect $v$. This result will be important when we consider changes in laws affecting retirement accounts.

\section{The Prediction for Value-Output and Capital-Output Ratios}

We show here that while the capital-output ratios are affected by the corporate income tax rate and subsidies to investment, they are not affected by the tax rate on corporate distributions if changes in tax revenues are exactly offset by transfers. This result will be important for understanding what has happened in the United States and the United Kingdom in the last 40 years.

Proposition 2. If two economies $A$ and $B$ are identical except that $(i)$ their tax rates on distribu- 
tions are not equal, $\tau_{\text {dist }}^{A} \neq \tau_{\text {dist }}^{B}$, and (ii) the difference in transfers offsets the difference in revenues

from distributions, $\psi_{t}^{A}-\psi_{t}^{B}=\tau_{\text {dist }}^{A} d_{t}^{A} s_{t}^{A}-\tau_{\text {dist }}^{B} d_{t}^{B} s_{t}^{B}$, then the equilibrium paths of the economies $A$ and $B$ are the same except for the price of corporate equity, $v_{t}$.

Proof: The stand-in firm in the two economies faces the same maximization problem except for a multiplicative factor in the objective function. Similarly, the budget constraints of households place the same constraints on consumption and labor supply provided that condition ( $i i$ ) holds. By Walras' law, the government budget constraints will also be satisfied in both economies. From (12), therefore, $v_{t}^{A} /\left(1-\tau_{\text {dist }}^{A}\right)=v_{t}^{B} /\left(1-\tau_{\text {dist }}^{B}\right)$.

In particular, the ratios of capital to output will not depend on the tax rate on corporate distributions. ${ }^{10}$ It is clear from (10) and (11), however, that they do depend on corporate income tax rates and investment subsidies.

\section{Application to the United States}

We now use the theory just described to identify the key policy changes that have affected U.S. equity markets over the last 40 years. Between 1960 and 2001, there was a large decline in the effective tax rate on corporate distributions and a modest decline in the tax rate on corporate income. Using the theory, we would predict that such policy changes would produce a large increase in the value of U.S. corporate equity relative to GDP between these years with a small increase in the corporate capital-output ratios. This is what we observe. In the late 1970s and early 1980s, there were significant subsidies for tangible investment - which were then eliminated with the 1986 Tax Reform Act. Using the theory of Section 2, we would predict a large decline in the price of measured capital and a temporary rise in that stock of capital. Again, this is what we observe. Here we ask whether or not the predicted magnitudes of the changes roughly match the U.S. experience. We find that they do.

We first review the primary tax and regulatory changes that occurred in the United States between 1960 and 2001 which led to a decline in the effective tax rate on distributions, the temporary rise in capital subsidies, and the slow transition to higher stock values. We then extend the theory to include details for the U.S. economy; the extensions are needed to facilitate matching the model with the data. We show that none of the theoretical results change. Finally, we report our quantitative findings. 


\section{A. Changes in U.S. Taxes and Regulations}

In the 1960-2001 period, there were changes in the tax and regulatory system that had important effects on the rates $\tau_{d i s t}, \tau_{c o r p}$, and $\tau_{\text {subs }}$.

\section{Tax rate on corporate distributions}

Three changes during the period reduced the tax rate on corporate distributions $\tau_{\text {dist }}$. First, individual income tax rates fell. Second, strict regulations on fiduciaries were relaxed, which led the fraction of equity held by nontaxed entities to rise. Third, regulations on share repurchases, which had a tax advantage over dividends, were relaxed.

Between 1964 and 1986, there were three cuts in individual income tax rates. The first was the Revenue Act of 1964, which reduced the highest marginal income tax rate from 91 percent to 70 percent. Next, there was the Economic Recovery Tax Act (ERTA) of 1981, which reduced the highest rate to 50 percent. Finally, there was the TRA of 1986, which reduced the marginal tax rate on the highest incomes to 28 percent. These rate reductions implied a drop in marginal rates paid on dividends, since dividends are taxed as ordinary income.

A second change that affected the tax rate on corporate distributions was a change in the regulations governing pension funds and retirement accounts, which do not pay tax on distributions. ${ }^{11}$ A major change came in 1974 when the Employment Retirement Income Security Act (ERISA) was enacted. Before this act was passed, there were few guidelines on what constituted imprudent behavior by fiduciaries. Fiduciary breaches were dealt with in the U.S. courts, case by case. During this early period, pension fund portfolios were primarily debt assets. Fiduciaries managing pension funds chose not to hold equity because of the risk of being sued if the value of equity fell.

With the enactment of ERISA, pension funds became regulated intermediaries, and uniform fiduciary standards were established. The standards pertaining to prudent behavior by fiduciaries were further clarified in 1979 by the U.S. Department of Labor (Section 404(a)(1) of Rules and Regulations for Fiduciary Responsibility). If a fiduciary complied with the prudence regulation, the investments made were deemed prudent, and the fiduciary was not held to be personally liable. During the period following these legal changes, pension fund equity holdings increased significantly, and the effective tax on distributions declined significantly.

Changes in tax law also led to a rise in nontaxed retirement accounts. In the late 1970s 
and early 1980s, there were major changes in tax law that fostered individual retirement accounts (IRAs) and defined contribution pension plans. The funds in these retirement plans are invested in individual accounts, with the individual typically having considerable latitude in how these funds will be invested. A consequence of these tax law changes is that equity holdings in these plans grew rapidly in the 1980s and 1990s. The percentage of corporate equity held by all nontaxed entitiesnamely, pension funds, individual retirement accounts, and nonprofit organizations - increased from 4 percent in 1960 to 51 percent in 2000. With more equity in nontaxed or tax-deferred accounts, the effective tax rate on corporate distributions is lower.

A third change that affected the tax rate on distributions was a change in regulations governing share repurchases. The 1954 Internal Revenue Code (Section 302) states that buybacks that are "substantially disproportionate" are taxed at the capital gains rate, which for most years since 1960 was lower than the ordinary rate used for dividend income. (See Bittker and Eustice (2000), Chapter 9.) In spite of this provision, buybacks were little used as a means to make distributions of earnings to stockholders prior to 1977. In that year, IBM became the first major corporation to make distributions via buybacks with a $\$ 1.4$ billion repurchase of its shares. The fact that this buyback was treated as a capital gain set a precedent. Publicly traded corporations no longer had to worry that market repurchases would be treated as dividends. Grullon and Michaely (2002) examine data for all the corporations in the Standard \& Poor's COMPUSTAT database for the period 1972-2000. They report that buybacks increased from under 5 percent of total distributions in 1977 to over 50 percent in $2000 .^{12}$

Most of the increase in repurchases actually occurred after 1997. Prior to that, SEC and IRS rules gave little, if any, incentive for companies to buy back shares. Under the rules in place prior to 1982, the SEC could and often did charge companies with illegally manipulating their stock prices during stock repurchase programs. (See sections 9 and 10 of the Security Exchange Act of 1934.) In 1982, the SEC adopted Rule 10b-18, which essentially provided a safe harbor for buybacks. Rule 10b-18 gives specific guidelines to companies and brokers for repurchase programs. ${ }^{13}$ With the 1986 TRA, the difference in the tax rate on capital gains and dividends virtually disappeared and, therefore, so did the incentive for buybacks. In 1991, the law was changed again, and the maximum rate on capital gains dropped below the maximum rate on ordinary income. The difference, however, was small. Not until 1997, when the rate on long-term capital gains was lowered to 20 percent did buybacks increase significantly. (See Grullon and Michaely (2002).) 
In McGrattan and Prescott (2003b), we provide all of the details on our estimated tax rate on distributions, $\tau_{\text {dist }}$. Briefly, what we do is first compute marginal rates on the distribution income for all groups receiving any, and then we weight these rates using the fractions of the distributions received. ${ }^{14}$ We document that the effective tax rate on dividend distributions averaged 41 percent in the period 1960-69 and 17 percent in the period 1990-2001. In the earlier period, the tax rate on dividends is the relevant tax rate for corporate distributions because of the restrictions on share buybacks. In the later period, distributions were made through dividends and share repurchases, but we find that the differences in effective tax rates for dividends and capital gains from share repurchases are quantitatively small. (See McGrattan and Prescott (2003b).) Thus, we use our estimate for the tax rate on dividends for $\tau_{\text {dist }}$ in our later calculations.

\section{Tax rate on corporate income}

A second tax that affects the value of corporate equity is the income tax rate on corporations $\tau_{\text {corp }}$. The corporate income tax rate has fallen over the period 1960-2001, but much less dramatically than the tax rate on corporate distributions.

We measure the corporate income tax rate as the ratio of the corporate profits tax liability in the U.S. national income and product accounts (NIPA) to before-tax corporate profits. In calculating the tax rate, we do not include the Federal Reserve Banks' taxes and profits. We eliminate

the Federal Reserve Banks because essentially all of their profits are given to the U.S. Treasury, and their tax rate is therefore 100 percent.

Our measure of the corporate income tax includes federal, state, and local profits tax accruals. Total profits tax liabilities have fallen, but by less than federal tax reports would indicate. Over time, there has been a rise in the state and local profits tax accruals relative to federal tax accruals.

We estimate an average U.S. corporate income tax rate in the period 1960-69 of 43 percent. In the period 1990-2001, our estimate is 35 percent. This is a much less dramatic decline than that for the tax rate on corporate distributions, which fell from 41 percent on average to 17 percent- - to just half the current corporate income tax rate. If we do not exclude the Federal Reserve Banks, the average corporate income tax rate in the periods 1960-69 and 1990-2001 are 44 percent and 38 percent, respectively. 


\section{Subsidies to capital investment}

U.S. capital subsidies were negligible in the 1960s and subsequent to the 1986 Tax Reform Act. They became significant in the 1970s and large in the 1981-86 period. The two important forms of subsidies were investment tax credits for the purchase of new capital goods and allowed depreciation in excess of economic depreciation.

Investment tax credits were introduced in 1962, repealed in 1969, reintroduced in 1971, and eliminated in 1986. These credits were small relative to corporate investment except in the late 1970s and early 1980s, when they were about 6 percent of total corporate investment.

Depreciation allowances in excess of economic depreciation are another form of investment subsidy. Throughout the 1960-81 period, the IRS shortened what it refers to as the "useful lives" of capital goods. This shortening increased the rate at which capital could be depreciated for tax purposes. If we use the data in King and Fullerton (1984) for their 34 categories of investment goods, we estimate that the average useful lives of capital goods were reduced by a factor of 1.54 in the $1960 \mathrm{~s}$, by a factor of 1.15 in the $1970 \mathrm{~s}$, and by a factor of 2.20 (as a result of ERTA) in $1981 .{ }^{15}$

\section{B. Model of the U.S. Economy}

To quantify the effects of particular U.S. tax and regulatory policy changes, we need to extend the original model to include details relevant to the U.S. economy. First, we allow for two sectors, corporate and noncorporate. ${ }^{16}$ Even though our primary focus is on corporate equity, the corporate sector accounts for less than 60 percent of U.S. value-added and has only one-third of all tangible assets. Second, we include the primary sources of U.S. tax revenues: taxes on consumption, taxes on labor income, taxes on corporate distributions, taxes on corporate income, and taxes on property. We will show that the basic corporate equity pricing formula, equation (12), does not change for this more general model economy. We will also show that capital-output ratios are not affected by changes in the tax rate on corporate distributions, as we found before.

We start with a description of preferences and technologies. The population in period $t$ is denoted by $N_{t}$ and grows at rate $\eta$, so $N_{t+1}=(1+\eta) N_{t}$. The stand-in household's preferences are ordered by

$$
\sum_{t=0}^{\infty} \beta^{t} U\left(c_{t}, n_{t}\right) N_{t}
$$


where $c$ and $n$ are per-capita consumption and labor supply, respectively. The corporate sector is denoted by 1 and the noncorporate sector by 2 . The tangible capital inputs are measured and are denoted by $k_{j m}$ for sector $j$. The intangible capital input in sector 1 is not measured and is denoted by $k_{1 u}$. Note, sector 2 has no intangible capital input. The motivation for this abstraction is that research and development $(\mathrm{R} \& \mathrm{D})$ takes place in the pharmaceutical company but not at the corner drugstore.

The output of sector $j$ is denoted by $y_{j}$. Sector outputs are combined to produce a composite good which is used for either private consumption or government consumption or for one of the categories of investment,

$$
c_{t}+g_{t}+x_{1 m, t}+x_{1 u, t}+x_{2 m, t} \leq y_{t}=F\left(y_{1, t}, y_{2, t}\right)
$$

where $g$ is government consumption, $x_{j m}$ is gross investment in measured tangible capital in sector $j$, and $x_{1 u}$ is gross investment in unmeasured intangible capital in sector 1.

The technology of sector 1 is described by

$$
\begin{aligned}
y_{1, t} & \leq f^{c}\left(k_{1 m, t}, k_{1 u, t}, z_{t} n_{1, t}\right) \\
k_{1 m, t+1} & =\left[\left(1-\delta_{1 m}\right) k_{1 m, t}+x_{1 m, t}\right] /(1+\eta) \\
k_{1 u, t+1} & =\left[\left(1-\delta_{1 u}\right) k_{1 u, t}+x_{1 u, t}\right] /(1+\eta) .
\end{aligned}
$$

Similarly,

$$
\begin{aligned}
y_{2, t} & \leq f^{n c}\left(k_{2 m, t}, z_{t} n_{2, t}\right) \\
k_{2 m, t+1} & =\left[\left(1-\delta_{2 m}\right) k_{2 m, t}+x_{2 m, t}\right] /(1+\eta) .
\end{aligned}
$$

All technologies have constant returns to scale. In (15) and (18), $n_{j}$ is labor services in sector $j$ and the $\left\{z_{t}\right\}$ are technology parameters that grow at rate $\gamma$. The right hand sides of the capital accumulation equations are divided by the growth in population $(1+\eta)$ because stocks and investments are in per-capita units.

We now introduce taxes and regulations. Households pay taxes on consumption at rate $\tau_{c}$, corporate distributions received at rate $\tau_{d}$, interest income at rate $\tau_{b}$, and labor income at rate $\tau_{n}$. 
The constraints of the household are the budget constraint, ${ }^{17}$

$$
\begin{aligned}
\sum_{t=0}^{\infty} p_{t}\{(1+ & \left.\left.\tau_{c}\right) c_{t}+v_{1 s, t}\left(s_{1, t+1}-s_{1, t}\right)+v_{2 s, t}\left(s_{2, t+1}-s_{2, t}\right)+b_{t+1}-b_{t}\right\} \\
& \leq \sum_{t=0}^{\infty} p_{t}\left\{\left(1-\tau_{d}\right) d_{1, t} s_{1, t}+d_{2, t} s_{2, t}+\left(1-\tau_{b}\right) r_{b, t} b_{t}+\left(1-\tau_{n}\right) w_{t} n_{t}+\psi_{t}\right\}
\end{aligned}
$$

The values of shares held in corporate and noncorporate firms are $v_{1 s, t} s_{1, t}$ and $v_{2 s, t} s_{2, t}$, respectively, where $v$ is the price and $s$ is the number of shares held. The total number of shares outstanding is normalized to 1 in each sector. Government bonds are also held and denoted by $b$. The interest rate earned on these bonds is $r_{b}$. Transfers of the government are denoted by $\psi$.

The distributions paid to households are equal to what firms have after making new investments, paying wages, paying taxes, and receiving subsidies:

$$
\begin{gathered}
d_{1, t}=p_{1, t} y_{1, t}-x_{1 m, t}-x_{1 u, t}-w_{t} n_{1, t}-\tau_{1 k} k_{1 m, t} \\
\quad-\tau_{1}\left[p_{1, t} y_{1, t}-\hat{\delta}_{1 m} \hat{k}_{1 m, t}-\hat{\delta}_{1 x} x_{1 m, t}-x_{1 u, t}-w_{t} n_{1, t}-\tau_{1 k} k_{1 m, t}\right]+\tau_{x} x_{1 m, t} \\
d_{2, t}=p_{2, t} y_{2, t}-x_{2 m, t}-w_{t} n_{2, t}-\tau_{2 k} k_{2 m, t} \\
\quad-\tau_{2}\left[p_{2, t} y_{2, t}-\hat{\delta}_{2 m} \hat{k}_{2 m, t}-\hat{\delta}_{2 x} x_{2 m, t}-w_{t} n_{2, t}-\tau_{2 k} k_{2 m, t}\right]+\tau_{x} x_{2 m, t}
\end{gathered}
$$

where $p_{j}$ is the price of goods in sector $j, w$ is the wage rate, $\tau_{j k}$ is the tax rate on property in sector $j, \tau_{j}$ is the tax rate on income in sector $j$, and $\tau_{x}$ is the investment tax credit. The term $\hat{\delta}_{j m} \hat{k}_{j m, t}$ $+\hat{\delta}_{j x} x_{j m, t}$ is the allowed depreciation on tangible capital in sector $j$ and is used to compute taxable income. The depreciation rates $\hat{\delta}_{j m}$ and $\hat{\delta}_{j x}$ are policy parameters that can be set to effectively lower the price on new capital, as in the cases of the United States and the United Kingdom. The rate $\hat{\delta}_{j m}$ is the allowed rate of depreciation on sector- $j$ book "capital", which has a law of motion,

$$
\hat{k}_{j m, t+1}=\left[\left(1-\hat{\delta}_{j m}\right) \hat{k}_{j m, t}+\left(1-\hat{\delta}_{j x}\right) x_{j m, t}\right] /[(1+\eta)(1+\pi)] .
$$

The right side of $(23)$ is divided by $(1+\eta)$ because units are per capita and by the gross inflation rate, $(1+\pi)$, because units are in real terms. The rate $\hat{\delta}_{j x}$ is the allowed rate of immediate expensing of investment in sector $j$. 
In equilibrium, firms in the corporate sector choose capital and labor to solve

$$
\max \sum_{t=0}^{\infty} p_{t} d_{1, t}\left(1-\tau_{d}\right)
$$

subject to constraints (15)-(17) and (23) for $j=1$. Noncorporate firms solve a similar problem

$$
\max \sum_{t=0}^{\infty} p_{t} d_{2, t}
$$

subject to constraints (18)-(19) and a constraint analogous to (23) for $j=2$. Note that $d_{2, t}$ is noncorporate income net of taxes.

Government production is included in the noncorporate sector. Government purchases and transfers are financed by tax receipts and debt issues. The period $t$ government budget constraint must be satisfied each period and is given by

$$
g_{t}+\psi_{t}+r_{b, t} b_{t}=b_{t+1}-b_{t}+\text { all tax receipts. }
$$

Note that all tax rates are proportional in our model economy.

We now show that the taxes on consumption, labor, property, and interest do not affect the corporate equity value. To do this, we use (15)-(17) to replace $y_{1, t}, x_{1 m, t}$, and $x_{1 u, t}$, respectively, in the corporate firm's problem. The problem then simplifies to maximizing (24) subject to (23) with $j=1$. This constraint has a multiplier $\lambda_{t} p_{t}$.

Proposition 3. An equilibrium relation specifying the total value of corporate equity, $V_{t} \equiv v_{1 s, t} N_{t}$, as a function of tax rates and corporate capital stocks is

$$
V_{t}=\left(1-\tau_{d}\right)\left[\left(1-\tau_{x}-\tau_{1} \hat{\delta}_{1 x}-\left(1-\hat{\delta}_{1 x}\right) \lambda_{t}\right) K_{1 m, t+1}+\lambda_{t}(1+\pi) \hat{K}_{1 m, t+1}+\left(1-\tau_{1}\right) K_{1 u, t+1}\right]
$$

where capital letters denote aggregates.

\section{Proof: See Appendix B.}

If we extend the model to allow for tax and inflation rates that vary deterministically or stochastically, the relation in equation (27) does not change except that these rates would be indexed by $t$. This is the case provided that investment is always positive and all investments are financed by retained earnings. 
In the simple model of Section 2, we were not specific about the capital subsidies. For the United States and the United Kingdom, the primary capital subsidies that have been used are the investment tax credit and accelerated depreciation allowances. If the only subsidy in place is the investment tax credit, equation (27) simplifies to (12) with $\tau_{d i s t}=\tau_{d}, \tau_{s u b s}=\tau_{x}$, and $\tau_{\text {corp }}=\tau_{1}$. If accounting and economic depreciation are not equal, as is the case with accelerated depreciation, then the formula for corporate equity is more complicated as it involves the value of book capital and a multiplier $(\lambda)$ that is unobserved. In this case, we need specific assumptions about the expectations of future tax rates, inflation, and productivity shocks to compute $\lambda_{t}$.

A useful benchmark for highlighting the quantitative importance of accelerated depreciation allowances is the relation (27) on a balanced growth path.

Proposition 4. On a balanced-growth path, the total value of corporate equity satisfies

$$
V_{t}=\left(1-\tau_{d}\right)\left[\left(1-\tau_{x}-\tau_{\delta}\right) K_{1 m, t+1}+\left(1-\tau_{1}\right) K_{1 u, t+1}\right]
$$

where

$$
\tau_{\delta}=\tau_{1}\left[\hat{\delta}_{1 x}+\left(1-\hat{\delta}_{1 x}\right)\left(\frac{\hat{\delta}_{1 m}}{i+\pi+\hat{\delta}_{1 m}}\right)\left(\frac{\left(1-\delta_{1 m}\right)(1+\pi)-1+\hat{\delta}_{1 m}}{\gamma+\eta+\pi+\hat{\delta}_{1 m}}\right)\right]
$$

Here, second-order terms are dropped and $i$ is the real interest rate.

Proof: See Appendix B.

This proposition says that the formula for the equity value on a balanced growth path is the same as (12), but with $\tau_{\text {dist }}=\tau_{d}, \tau_{\text {subs }}=\tau_{x}+\tau_{\delta}$, and $\tau_{\text {corp }}=\tau_{1}$.

The two extreme cases for accelerated depreciation allowances will turn out to be of interest. The first case is that of immediate expensing, with $\hat{\delta}_{1 x}=1$. In this case, all tangible investment is expensed, so $\tau_{\delta}=\tau_{1}$. The second case is that of no accelerated depreciation, with the book value of tangible capital equal to the market value of tangible capital. In this second case, $\tau_{\delta}=0$.

For this more general economy, we have the same result as our Proposition 2.

Proposition 5. If two economies $A$ and $B$ are identical except that $(i)$ their tax rates on distributions are not equal, $\tau_{d}^{A} \neq \tau_{d}^{B}$, and $(i i)$ the difference in transfers offsets the difference in revenues 
from distributions, $\psi_{t}^{A}-\psi_{t}^{B}=\tau_{d}^{A} d_{1, t}^{A} s_{1, t}^{A}-\tau_{d}^{B} d_{1, t}^{B} s_{1, t}^{B}$, then the equilibrium paths of the economies $A$ and $B$ are the same except for the price of corporate equity, $V_{t}$.

Proof: The proof is the same as that for Proposition 2.

Proposition 5 says that a change in the tax rate on dividend income affects only the price of corporate equity and nothing else. This will be important when we consider the U.S. data because there was little change in U.S. capital-output ratios at the same time that there were large changes in the value-output ratio. This proposition suggests that the tax rate on distributions was a potentially important factor.

Our model economy is closed. However, U.S. corporations have operations and, therefore, capital abroad, and their equity values will reflect that. For this reason, we work with the following modification of (28):

$$
V_{t}=\left(1-\tau_{d}\right)\left[\left(1-\tau_{x}-\tau_{\delta}\right) K_{1 m, t+1}+\left(1-\tau_{1}\right) K_{1 u, t+1}+K_{t+1}^{*}\right]
$$

where $K^{*}$ is the value of the foreign capital after income taxes and subsidies.

\section{Predictions of Theory}

We now apply formula (30), using estimates of U.S. tax rates and capital stocks, and derive the quantitative predictions of the growth model described above. We compare periods with different tax and regulatory policies and quantify the effects of changes in policy for changes in corporate valuations.

We find that theory predicts the data well. We start with a comparison of the 1960s and late 1990s-early 2000s and show that the large decline in the effective marginal tax rate on corporate distributions is a quantitatively important factor for the rise in equity values between the 1960s and 2000. We then compare the 1960s with the late 1970s-early 1980s and show that higher capital subsidies are a major factor for the low equities in the 1970s relative to the 1960s.

\section{The rise in equity values between 1960 and 2001}

We start with the dramatic difference between equity values in the 1960s and the late 1990searly 2000s. To apply the formula (30), we need values for tax rates and capital stocks in these periods. 
Table 1. U.S. Tax Rates and Credits Across and Within Periods

\begin{tabular}{|c|c|c|}
\hline & 1960-69 & 1990-2001 \\
\hline \multicolumn{3}{|c|}{ TAX on Corporate Income } \\
\hline End of period & 45.0 & 34.9 \\
\hline Average for period & 43.2 & 35.3 \\
\hline \multicolumn{3}{|c|}{ TAX on Corporate Distributions ${ }^{a}$} \\
\hline End of period & 41.8 & 17.3 \\
\hline Average for period & 41.1 & 17.4 \\
\hline \multicolumn{3}{|l|}{ Investment Tax Credit } \\
\hline End of period & 2.2 & 0.0 \\
\hline Average for period & 2.0 & 0.0 \\
\hline
\end{tabular}

$a_{\text {These estimates are based on data through } 2000 .}$

Table 1 reports the U.S. tax rates used in the evaluation. ${ }^{18}$ As Table 1 shows, average rates and end-of-period rates are about the same during the two periods, which is not surprising because tax policy changed little within these periods. We assume that people do not expect major changes in policy in the future that would put them on the investment corner in the current period.

The empirical counterpart of our model's measured corporate capital $K_{1 m}$ is the sum of the BEA's estimate of fixed corporate capital stocks and inventory stocks and the IRS's estimate of the value of corporate-owned land. The value of the measured corporate capital stock is close to one GDP in both periods. It was above one in the late 1970s and early 1980s when subsidies for new capital were in place.

The value of the stock of intangible capital is not measured by the BEA and must be estimated. We take an indirect approach, using observations on corporate profits and returns to tangible assets to estimate a return to intangible assets. An assumption of equal after-tax returns to tangible and intangible assets allows us to infer the stock of intangible capital.

NIPA corporate profits are as follows:

NIPA profit in $t=p_{1, t} y_{1, t}-w_{t} n_{1, t}-\delta_{1 m} k_{1 m, t}-\tau_{1 k} k_{1 m, t}-x_{1 u, t}$ 


$$
\begin{aligned}
& =\frac{i}{1-\tau_{1}} k_{1 m, t}+\left(i+\delta_{1 u}\right) k_{1 u, t}-\left(\gamma+\eta+\delta_{1 u}\right) k_{1 u, t} \\
& =\frac{i}{\left(1-\tau_{1}\right)\left(\gamma+\eta+\delta_{1 m}\right)} x_{1 m, t}+(i-\gamma-\eta) k_{1 u, t}
\end{aligned}
$$

where recall that for sector $1, p_{1, t} y_{1, t}$ are sales of goods, $w_{t} n_{1, t}$ is compensation, $\delta_{1 m} k_{1 m, t}$ is depreciation of tangible assets, $\tau_{1 k} k_{1 m, t}$ is the property tax, $x_{1 u, t}$ is intangible investment, $k_{1 m, t}$ is the tangible capital stock, $k_{1 u, t}$ is the intangible capital stock, and $\delta_{1 u}$ is the depreciation rate of intangible capital. In writing (32) and (33), we have assumed constant levels of the real interest rate $(i)$, the growth rates of labor-augmenting technological change $(\gamma)$, and the growth rates of population $(\eta)$. We also assume that economic and accounting depreciation are equal.

The first term in (33) is the contribution from tangible investments, and the second is the contribution from intangible investments. An assumption in deriving this relation is that returns across asset types are equated. We residually derive $k_{1 u, t}$ with a measure of corporate profits from NIPA, tangible corporate investment $x_{1 m, t}$, the real interest rate $i$, the corporate tax rate $\tau_{1}$, and growth rates of technology and population. Note that this calculation does not require knowledge of the rate of depreciation of intangible capital.

Table 2 reports our estimates of intangible capital for the United States over the periods 1960-69 and 1990-2001. The estimates for the corporate tax rate are taken from Table 1. Real growth rates for GDP are the sum of growth in technology and growth in population. Growth in technology was about one percentage point higher in the 1960s than in 1990-2001; we assume 3 percent in the 1960s and 2 percent in 1990-2001. Population growth rates for the 20-64 working age population are comparable in the two periods, at roughly 1 percent.

With log preferences, the real interest rate is equal to $[(1+\gamma) / \beta]-1$, where $\gamma$ is the growth rate of the technology parameter and $\beta$ is the discount factor. We set $\beta$ equal to 0.98 for both periods, which implies a real interest rate of 5.1 percent in the $1960 \mathrm{~s}$ and 4.1 percent in the $1990 \mathrm{~s} .{ }^{19}$

Measures of corporate investment are taken from the Federal Reserve's Flow of Funds Accounts. ${ }^{20}$ The depreciation rates of measured corporate investment along with the growth rates and average investment rates imply corporate measured capital stocks equal to one GDP.

Given the rates at the top of Table 2, we estimate the contributions of tangible and intangible assets to domestic pre-tax profits. For the 1960s, we find that 92 percent of domestic pre-tax 


\begin{tabular}{|c|c|c|}
\hline & $1960-69$ & $1990-2001$ \\
\hline \multicolumn{3}{|l|}{ U.S. VALUES } \\
\hline Corporate tax rate $\left(\tau_{1}\right)$ & .450 & .349 \\
\hline Growth of real GDP $(\gamma+\eta)$ & .040 & .030 \\
\hline Real interest rate $(i)$ & .051 & .041 \\
\hline Tangible depreciation rate $\left(\delta_{1 m}\right)$ & .042 & .067 \\
\hline Average corporate investment ${ }^{a}\left(x_{1 m}\right)$ & .082 & .097 \\
\hline \multicolumn{3}{|l|}{ Contributions to domestic pre-tax profits ${ }^{a}$} \\
\hline Tangible assets $\left[i x_{1 m} /\left[\left(1-\tau_{1}\right)\left(\gamma+\eta+\delta_{1 m}\right)\right]\right]$ & .093 & .063 \\
\hline Intangible assets $\left[(i-\gamma-\eta) k_{1 u}\right]$ & .008 & .007 \\
\hline Total & .101 & .070 \\
\hline ESTIMATE OF INTANGIBLE CAPITAL $^{a}\left(k_{1 u}\right)$ & .714 & .650 \\
\hline
\end{tabular}

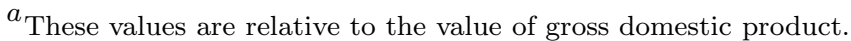

corporate profits is the contribution from tangible assets. For the 1990s, we find a similar result at 90 percent. Inferring the stock of intangible capital using formula (33), we find that it is 0.714 GDP in the 1960s and 0.650 GDP in the 1990s.

Our estimates of intangible capital are in the range of those found in the literature. ${ }^{21}$ Corrado et al. (2005) estimate that intangible investments not included in the NIPA are between 4.4 and 10.6 percent of GDP for the period 1998-2000. The lower end of this range is the sum of direct measures of R\&D investments, advertising costs, and copyright and license costs; the upper end of the range is the sum of these direct measures plus indirect measures of firm-specific human capital investments and costs of organizational change and development.

Unlike in our method, a depreciation rate is needed in order to infer the magnitude of intangible capital stock from Corrado et al.'s estimate of intangible investment. The BEA estimates a rate of depreciation of 11 percent for $\mathrm{R} \& \mathrm{D}$ investment. If we use this estimate for the depreciation rate of all intangible stocks included in Corrado et al.'s measure, then the implied range of the intangible capital stock $k_{1 u}$ is from 0.31 to 0.76 GDP. We think an 11 percent depreciation rate is on the high side for most of non-R\&D intangible capital investment. We also think that their 
Table 3. Predicted and Actual U.S. Corporate Values

\begin{tabular}{|c|c|c|}
\hline & $1960-69$ & $1998-2001$ \\
\hline \multicolumn{3}{|l|}{ Predicted Fundamental Values $^{a}$} \\
\hline Domestic tangible capital & .563 & .838 \\
\hline Domestic intangible capital & .229 & .350 \\
\hline Foreign capital & .086 & .379 \\
\hline Total Relative to GDP & .877 & $\overline{1.567}$ \\
\hline Total Relative to Earnings ${ }^{b}$ (P/E) & 13.5 & 27.5 \\
\hline \multicolumn{3}{|l|}{ Actual Market Values ${ }^{a}$} \\
\hline Corporate equities & .898 & 1.576 \\
\hline Net corporate debt & .041 & .028 \\
\hline Total Relative to GDP & $\overline{.940}$ & $\overline{1.604}$ \\
\hline Total Relative to Earnings ${ }^{b}(\mathrm{P} / \mathrm{E})$ & 14.5 & 28.1 \\
\hline
\end{tabular}

${ }^{a}$ All values are relative to GDP except the price-earnings ratio.

${ }^{b}$ Earnings are after-tax national corporate profits reported in the NIPA.

estimate of what Prescott and Visscher (1980) call organization capital investment is conservative. Evidence for this view is the importance of firm-specific learning-by-doing and the difficulty that competitors have in reducing their costs to the level of the most efficient firms in the industry. (See Arrow, 1962 and Irwin and Klenow, 1994.) This evidence and the direct measures of Corrado et al. suggest that a reasonable range for the value of intangible capital is between 0.5 and 1.0 GDP.

The fact that our estimates of intangible capital in Table 2 are of similar magnitude in the 1960s and 1990s is also consistent with evidence on directly measured intangibles. According to surveys of the National Science Foundation (1953-2002), the amount of R\&D performed by the industrial sector was as large in the 1960s as in the 1990s, roughly 1.9 percent of GDP. According to data of the media agency Universal McCann (1929-2000), advertising expenditures as a percentage of GDP averaged 2.1 percent in the 1960s and 2.2 percent in the 1990s.

We now apply formula (30) to estimate U.S. corporate equity values and price-earnings ratios. Table 3 summarizes our main findings for the 1960s and for the late 1990s and early 2000s. ${ }^{22}$ Theory's prediction for the total value of U.S. corporations in the 1960s is 0.877 GDP. The actual value of equity was 0.898 GDP. Adding the value of net corporate debt of 0.041 GDP 
implies a total market value of 0.940 GDP. ${ }^{23}$ Theory's prediction for the value of U.S. corporations in the later period was $1.567 \mathrm{GDP}$, whereas the actual value of equity plus net debt was on average 1.609 GDP.

Table 3 also reports the predicted contributions from the three types of capital: tangible, intangible, and foreign. The contribution from tangible capital is found by multiplying its price $\left(1-\tau_{d}\right)\left(1-\tau_{x}\right)$ and its reproducible cost $k_{1 m}$. The price was 0.57 in $1960-69$ and 0.83 in 1998-2001 while the average reproducible cost reported by the BEA was roughly the same in the two periods: 0.99 GDP in 1960-69 and 1.03 GDP in 1998-2001.

For the contribution of intangible capital, we multiply the price of intangible capital (1 $\left.\tau_{d}\right)\left(1-\tau_{1}\right)$ by the cost of the reproducible capital $k_{1 u}$. The price was 0.32 in $1960-69$ and 0.54 in 1998-2001, while the average reproducible costs reported in Table 2 fell slightly, from 0.71 GDP in 1960-69 to 0.65 GDP in 1998-2001.

The last category of capital listed in Table 3 is foreign capital. The BEA estimates tangible capital located in the United States. But, we have no direct measures of tangible or intangible capital used by foreign subsidiaries. Another problem is how to measure the prices of foreign-subsidiary capital. Foreign subsidies and corporate income taxes vary by country and U.S. companies have subsidiaries in a large number of countries. Thus, it is difficult to get direct measures of the foreign capital $K^{*}$ in (30). The value of foreign capital can be written explicitly in terms of foreign tax rates and capital stocks as follows

$$
K_{t+1}^{*}=\sum_{c}\left(1-\tau_{x}^{c}-\tau_{\delta}^{c}\right) K_{1 m, t+1}^{c}+\left(1-\tau_{1}^{c}\right) K_{1 u, t+1}^{c}
$$

where $c$ is a country index.

Because we do not have direct estimates for the foreign subsidiary stocks and tax rates, we estimate the value of the stock of foreign capital by assuming that the ratio of domestic stocks to foreign subsidiary stocks $\left(K^{*}\right)$ is equal to the ratio of domestic corporate profits to foreign subsidiary corporate profits, after all values have been adjusted to account for subsidies and corporate income taxes. ${ }^{24}$ Doing this produces an estimate of foreign capital of 0.086 in the period 1960-69 and 0.379 in $1998-2001 .^{25}$

To check whether these estimates of $K^{*}$ are sensitive to different choices for foreign tax rates, we conducted the following experiment. We set the ratio of intangible and tangible the 
same in the United States as abroad. Then $K^{*}$ can be written in terms of the capital subsidies, the corporate income tax and the stock of tangible. If we normalize the stock in tangible to one, we can consider how variations in the tax rates - holding stocks fixed-affect the estimate of the stock of foreign capital in percentage terms. Suppose U.S. tax policies are the benchmark. In the 1960s, U.S. subsidies were 2.2 percent and the corporate income tax rate was 45 percent. Suppose foreigners offered more favorable tax provisions than the United States; how would that affect $K^{*}$ ? A 10 percent subsidy coupled with a 15 percent corporate income tax rate would imply $K^{*}$ is 9.9 percent higher than that implied by the U.S. 1960s tax rates. Thus instead of a value of 0.086 in Table 3, we would have 0.095. Doing the same exercise for the 1990s, when U.S. subsidies were negligible and the corporate income tax rate was 35 percent, we would find a $K^{*}$ that is 2.1 percent higher than that implied by the U.S. 1990s tax rates. Thus instead of a value of 0.379 in Table 3 , we would have 0.387 . These robustness tests show that our estimates are surprisingly insensitive to assumptions concerning foreign tax rates.

Also reported in Table 3 is the predicted price-earnings ratio for the two periods. In our calculations, we use the total value for the numerator and the after-tax national corporate profits for the denominator. The model's price-earnings ratio is 13.5 in the $1960 \mathrm{~s}$ and 27.5 in the recent period. These estimates are very close to the actual ratios of 14.9 and 28.2 , respectively. They are also close to estimates of Campbell and Shiller (2001), who look at only equities of the 500 companies in the Standard \& Poor's composite index.

Quantitatively, the most important change over the postwar period was the decline in the U.S. tax rate on corporate distributions. If the rate had remained at 41.8 percent, our prediction for the value of U.S. corporations in 1998-2001 would have been 1.1 GDP rather than 1.57 GDP. Also important was the increase in foreign capital.

Hall (2001) has argued that a rise in the stock of intangible capital accounts for the large increase in equity prices. He, however, does not estimate intangible capital, so it is impossible to evaluate his argument. We find that the value of intangible capital did rise- because its price fell. But the increase in the value of intangibles accounts for a change in the value of corporate equities of only 0.12 GDP.

Our main results are not sensitive to errors in measuring the intangible capital stock because the cost to the household of this stock is much less than its reproducible cost. These costs are 
different because investments in intangible capital can be financed using retained earnings and because these investments are expensed. For example, even if there were an error of 0.3 of GDP in measuring this stock, the change in our predicted values would be only 10 percent in both periods.

Our estimate for the total fundamental value in the period 1998-2001 changes only slightly if we allow for the fact that half of the distributions in 2000 were made through share repurchases. In McGrattan and Prescott (2003b), we demonstrate that the effective tax rate on dividends is not very different from the effective tax rate on buybacks even in the extreme case in which we assume that $(i)$ all repurchases are taxed like long-term gains and $(i i)$ the real gains are equal to the nominal gains. In this extreme case, the effective tax rate on distributions in year 2000 is 14.2 percent, and the prediction for the total fundamental value is $1.626 \mathrm{GDP}$, which is close to the predicted and actual values reported in Table 3.

The overall message of Table 3 is that changes in taxation, especially taxation of corporate distributions, are an important factor behind the rise in the value of U.S. corporations between the 1960s and the late 1990s and early 2000s.

\section{The low equity values in the $1970 \mathrm{~s}$}

Before U.S. equity values began their ascent in the late 1980s, they declined dramatically starting in 1973, when the value of corporate equity relative to GDP fell roughly by half. In this section, we explore three factors that account in large part for the low equity values after 1973. First, there was some swapping of debt-financing for equity-financing. Second, tax subsidies

were introduced in the United States that lowered the price of tangible capital. Third, many European countries had instituted extremely generous capital subsidies, which may well have led to expectations of similar subsidies in the United States.

One reason for the low corporate valuations in the 1970s was the substitution of debt for equity as personal income tax rates fell below corporate income tax rates. The average value of net corporate debt was 0.041 GDP in the 1960s. (See Table 3.) In the period 1973-79, the average was 0.108 GDP, more than double the 1960s level. Thus, although equity values fell by about half, the total corporate valuations fell by 37 percent from 0.940 GDP in the 1960s to 0.593 GDP in 1973-79.

Another reason for the low corporate valuations in the 1970s was the introduction of tax 
policies that lowered the price of new capital. We explore two such policies in the context of our model: investment tax credits and historic cost depreciation allowances in excess of economic depreciation. As Proposition 3 states, both policies depress corporate valuations.

A good measure of the effective credit on investment, $\tau_{x}$, is the ratio of total investment tax credits to total corporate gross investment, both available in the NIPA. Investment tax credits relative to corporate investment went from 2 percent in the 1960s to almost 6 percent in the period 1975-81. Credits were limited to certain types of investment, but there may well have been expectations of broader application of these credits.

The larger change in policy was the near tripling of the rate at which capital could be depreciated for tax purposes. We estimate that the consequence of this policy change was to increase $\tau_{\delta}$ from near 0 to 0.18 . Our estimate of 0.18 is based on average values for the U.S. economy in the second half of the 1970s. In our formula (29), we set $\tau_{1}=0.38, \delta_{1 m}=0.055, i=0.041, \gamma+\eta=0.03$, $\pi=0.07, \hat{\delta}_{1 m}=0.17$, and $\hat{\delta}_{1 x}=\hat{\delta}_{1 m} / 2$. We assumed that $\hat{\delta}_{1 x}=\hat{\delta}_{1 m} / 2$, because this implies that in the year of investment, the depreciation allowance is half of that in subsequent years. ${ }^{26}$

To summarize, subsidies to new capital investment, $\tau_{x}+\tau_{\delta}$, increased by about 22 percentage points. $^{27}$ If this were the only change that occurred in the 1970 s, then our prediction for the total value of U.S. corporations would be 0.738 GDP, 24 percent higher than the actual market value.

Another way to quantify the effect of the change in tax subsidies is to compare the predicted and actual differences in corporate valuations between the 1960s and 1970s. Again, assuming only a change in the total subsidy $\left(\tau_{x}+\tau_{\delta}\right)$, the model can account for 43 percent of the difference between the 1960s and 1970s average valuation relative to GDP. The actual value for the 1960s averaged 0.940 GDP, and was 36.9 percent lower in the second half of the 1970s. The predicted value for the 1960s averaged 0.877 GDP, and was 15.8 percent lower with our estimate of the higher U.S. subsidy rate.

Accounting fully for the effects of changes in policy during the 1970s requires modeling expectations of market participants and taking into account much more generous policies in Europe. The calculation above assumes that participants expected no further increase in subsidies. If they expected more generous tax allowances, similar to those already adopted in Europe, then market values could have fallen further even if the measures were never adopted. If, for example, U.S. companies expected policies like those in the United Kingdom which allowed for immediate 
Figure 2. Value of U.S. and U.K. Corporate Equities, 1960-2001

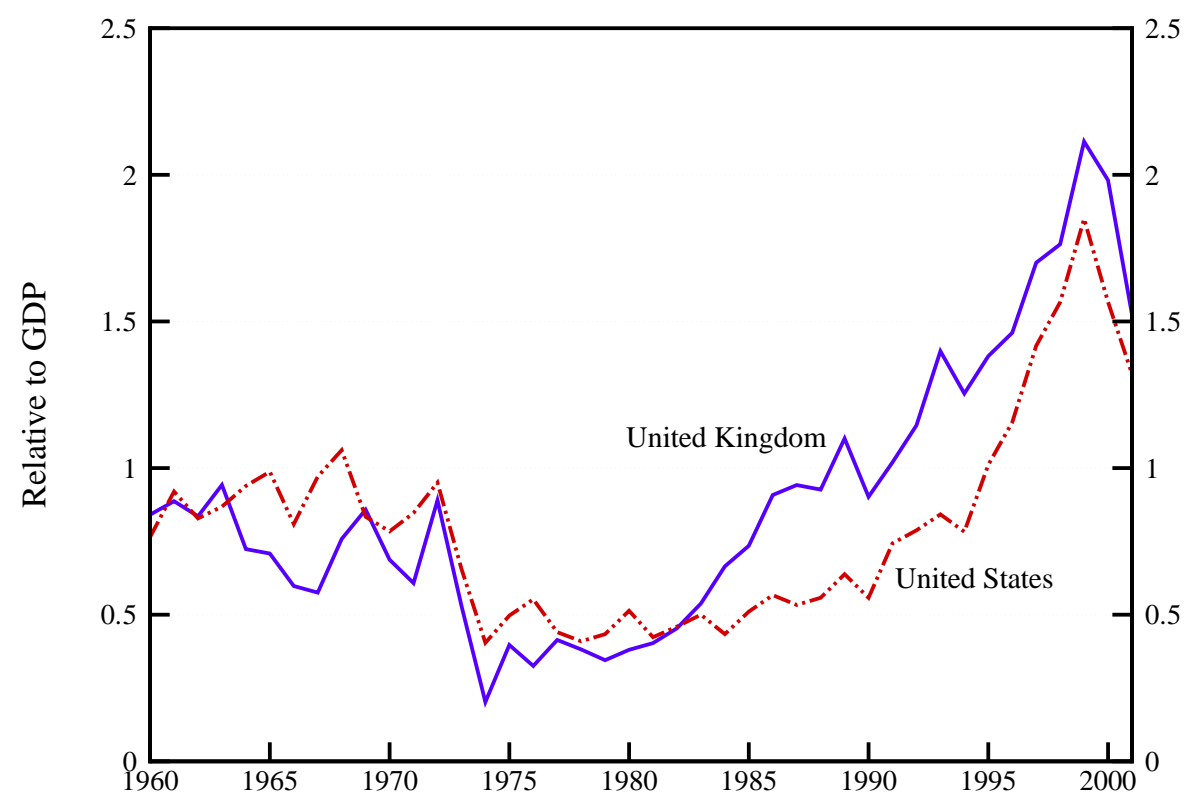

expensing on most investment goods, they might delay their investments and take advantage of a subsidy equal to the rate of corporate income tax (that is, $\tau_{\delta}=\tau_{1}$ ). In this case, the formula (30) has to be modified to include a multiplier associated with the constraint imposing nonnegativity on investment. When the constraint binds, the equity value falls by more than the right side of equation (30).

In summary, we find that increased tax subsidies are a quantitatively important factor for the low corporate valuations in the 1970s, accounting for 43 percent of the difference in corporate valuations between the 1960s and 1970s. Expectations of future increases in subsidies, to levels allowed in Europe, can further depress stock prices and may account for some of the deviation between actual and predicted valuations.

\section{Application to the United Kingdom}

We turn now to the movements in U.K. corporate valuations over the period 1960-2001. The patterns of U.S. and U.K. equity values are similar, with a large decline in the 1970s and a large run-up in the 1980s and 1990s. (See Figure 2. ${ }^{28}$ ) What distinguishes the patterns are the 
magnitudes of the changes in values. The decline and increase are significantly larger in the United Kingdom. In this section, we determine whether the movements in U.K. corporate equity values during 1960-2001 are accounted for by changes in the key fundamental factors we have identified for the movements in U.S. valuations: corporate net debt, the corporate capital stock, and the tax and regulatory policies facing corporations. We find some change in all of these factors, but the quantitatively important factor is the U.K. tax and regulatory system.

\section{A. Changes in U.K. Taxes and Regulations}

We begin with a review of changes in U.K. policies that affected the tax rate on distributions, the tax rate on corporate income, and subsidies to corporate investment during 1960-2001.

\section{Tax rate on corporate distributions}

Major tax reforms affecting corporate distributions occurred in 1965 and in 1973. In 1965, the United Kingdom introduced a system that was like that of the postwar United States. Corporations paid tax on profits at the corporate income tax rate and shareholders paid tax on dividends at the personal income tax rate. In 1973, what the U.K. Department of Inland Revenue calls a "partial imputation system" was introduced to mitigate double taxation when profits are distributed. Under this system, those receiving dividends are given a dividend credit that reduces their tax liability. For most years, a shareholder with marginal rates equal to the basic rate of income tax received credits that were just sufficient to cover the personal tax liability. A shareholder in a higher bracket received credits that partially offset the liability. And, until 1997, tax-exempt institutions received tax credits even though they had no tax liability.

Poterba and Summers (1984) estimate effective U.K. tax rates on dividend income for the period 1955-81. They estimate a tax rate of 42 percent for 1972, the year before the reintroduction of the partial imputation system. By 1976, their estimated tax rate falls below zero because of the large number of nontaxed equity holdings. Poterba and Summers estimate an effective tax rate for 1981 of minus 12.1 percent. Using the same procedure and data from the U.K. Inland Revenue Statistics, we estimate rates after 1981 and find that they remain negative until 1997. (See McGrattan and Prescott (2003b).)

Bond et al. (1996) point out what we view as a small problem with the Poterba and Summers (1984) estimates that we use. They note that the fall in the effective tax rate on dividends may 
have been more gradual than Poterba and Summers (1984) estimate. Until 1999, a company paid part of its corporate tax liability in advance when it paid a dividend. The purpose of this advance corporate tax (ACT) was to finance the dividend tax credit available to shareholders. Owners of a corporation with a tax liability that is less than its dividend payments could not fully benefit from the U.K. system and faced a higher tax cost of paying dividends. It is true that these corporations could carry over the difference to cover future tax liabilities, but Bond et al. (1996) estimate that in 1981, 37 percent of U.K. companies had made tax payments that were in fact irrecoverable. By 1990, fewer than 10 percent of companies had ACT payments exceeding the total tax liability. Thus, the comparison of the 1960s and 1990s that we do later is little affected by this factor.

With the tax advantages that U.K. pension funds received for dividend income, fund holdings of equities grew significantly as in the United States. Using data from the U.K. Share Ownership survey in 1969, we estimate that the domestic holding of equity (once we net out intercorporate holdings) in pensions was 19 percent. By 1993, pensions and individual retirement accounts accounted for 50 percent of domestic equity holdings. The share fell modestly after that because of two changes in U.K. law. First, in 1993, the dividend tax credit rate was no longer equal to the basic rate of income tax, but was set equal to the lower rate of income tax. Second, after 1997, tax-exempt institutions could no longer claim the dividend tax credit.

Thus far we have considered only distributions through dividends. Because of U.K. laws, share repurchases have been a very small fraction of corporate distributions over most of the period we study. According to Shirley (1997), not until the early 1980s were companies permitted to repurchase their own shares. But until 1997, pension funds preferred dividends to open market share buybacks because of the tax credits they received. With the elimination of tax credits for tax-exempt institutions, there has been an increase in share repurchases, but according to Office for National Statistics data, they are still a small part of corporate distributions. (See Hill and Taylor (2001).)

To summarize, the U.K. corporate tax system had a number of changes that led to a large decline in effective tax rates on corporate distributions. The decline in rates was even greater than that for the United States. In McGrattan and Prescott (2003b), we document that the effective U.K. tax rate on dividend distributions averaged 49.1 percent in the period 1960-69 and minus 5.3 percent in the period 1990-2001. In most years of our sample, the tax rate on dividends is the relevant tax rate for corporate distributions because of the restrictions on share repurchases or the 
tax advantages of dividends. In the future, share buybacks may increase since pension funds no longer receive dividend tax credits, but they are still a small part of corporate distributions. Thus, for our purposes, the relevant rate for $\tau_{d i s t}$ in later U.K. calculations is the tax rate on dividends.

\section{Tax rate on corporate income}

During the post-WWII period, corporate income tax rates in the United Kingdom have come down. The decline has been larger than that seen in the United States, but significantly smaller than the decline in the tax rate on U.K. corporate distributions.

King and Fullerton (1984) report an average tax rate of 47.7 percent in the 1960s. Based on data from the U.K. Inland Revenue Statistics, we estimate an average tax rate of 30.7 percent over the period 1990-2001. Thus, although it has come down, the rate on corporate income has been much higher than that on distributions for most of the period we study.

\section{Subsidies to capital investment}

In the United Kingdom, as in the United States, the main subsidies to capital investment are through corporate grants for the purchase of new capital goods and tax allowances for depreciation.

Investment grants were paid to U.K. corporations starting in 1967. According to King and Fullerton (1984), all investment in manufacturing, construction, and extractive industries automatically qualified for grants until 1970. Using data from the U.K. Central Statistical Office (1971), we estimate that grants were 12.7 percent of total corporate investment expenditures in 1969. With the Industry Act of 1972, there was a shift to more discretionary assistance in order to encourage development in certain regions, and by 1988 automatic grants were closed to new applications. For the period 1990-2001, we find that investment grants were small, averaging only 0.8 percent of corporate investment.

The larger U.K. subsidies were tax allowances for depreciation. Throughout the 1970s, the U.K. system had increasingly generous depreciation allowances. Inland Revenue Statistics reports that between March 1972 and March 1984, immediate expensing was allowed on all investment in machinery and plant and second-hand plant and ships. Starting in March 1972, industrial buildings received an initial allowance of 40 percent. By 1981, the allowance was up to 75 percent. Inventories received tax relief due to the high inflation in the 1970s. King and Fullerton (1984) estimate that 
the tax relief was so generous that it is appropriate to assume immediate expensing on the purchases of inventories.

These tax allowances were not unexpected policies; according to King and Robson (1993), depreciation allowances had been getting more and more generous. The introduction of such measures - especially if coupled with corporate tax rates as high as the United Kingdom hadimply a very significant fall in equity prices.

\section{B. Predictions of Theory}

We turn now to quantifying the effects of the changes in U.K. policies outlined above and comparing the results with those for the United States and with the predictions of our growth model. We focus on two particular observations for the value of U.K. corporations relative to GDP: (i) it nearly tripled between 1960 and 2001, and (ii) it nearly halved between 1960 and 1975, with both changes due primarily to movements in equity values relative to GDP. In this section, we show that changes in U.K. tax and regulatory policies are the critical factors for changes in U.K. corporate valuations.

\section{The rise in equity values between 1960 and 2001}

We start by comparing the 1960s with the period 1990-2001. In Table 4, we report our estimates for the tax rates, capital stocks, and ratio of foreign to domestic profits. For the purpose of comparison, we do this for both the United States and the United Kingdom. These are the relevant statistics for evaluating the formula (30).

We reviewed changes in tax rates above, and here we summarize these changes by displaying end-of-period values as well as averages in two periods: 1960-69 and 1990-2001. Relative to the U.S. rates, the U.K. rates we compute show slightly less constancy within these periods - especially the tax on corporate dividends in the later period and the investment subsidy in the early periodbut there is a similar pattern across periods. For both countries, tax rates on corporate profits and subsidies on investment fell somewhat, and tax rates on dividends fell dramatically.

Data on reproducible costs of tangible corporate assets are available from Roe (1971) for the period 1957-66. Roe has estimates of dwellings, other land and buildings, plant and equipment,

and stocks and work in progress for U.K. corporations. ${ }^{29}$ In Table 4, we report for the 1960s an 
Table 4. U.S. and U.K. Tax Rates, Capital Stocks, and Foreign Profits

\begin{tabular}{|c|c|c|c|c|}
\hline & \multicolumn{2}{|c|}{ U.S. } & \multicolumn{2}{|c|}{ U.K. } \\
\hline & 1960-69 & $1990-2001$ & 1960-69 & 1990-2001 \\
\hline \multicolumn{5}{|l|}{ TAX RATES } \\
\hline \multicolumn{5}{|l|}{ Corporate Profits } \\
\hline End of period & 45.0 & 34.9 & 43.1 & 28.9 \\
\hline Average & 43.2 & 35.3 & 47.7 & 30.7 \\
\hline \multicolumn{5}{|l|}{ Corporate Dividends } \\
\hline End of period & 41.8 & 17.3 & 46.9 & 3.9 \\
\hline Average & 41.1 & 17.4 & 49.1 & -5.3 \\
\hline \multicolumn{5}{|l|}{ Investment subsidy } \\
\hline End of period & 2.2 & 0.0 & 12.7 & 1.2 \\
\hline Average & 2.0 & 0.0 & 3.1 & 0.8 \\
\hline \multicolumn{5}{|l|}{ CAPITAL Stocks $^{a}$} \\
\hline Domestic tangible & .99 & 1.03 & 1.23 & 1.45 \\
\hline Domestic intangible & .71 & .65 & .66 & .51 \\
\hline Foreign/Domestic Profits & .11 & .29 & .04 & .29 \\
\hline
\end{tabular}

${ }^{a_{\text {Values }}}$ are relative to GDP. U.K. tangible stocks in the 1960s are available 1960-66.

average of 1.23 GDP, which is the average for 1960-66 using Roe's data. This is higher than the U.S. average of 0.99 GDP and may be due in part to higher corporate land values in the United Kingdom.

Recent estimates of tangible capital are available in the U.K. ONS Blue Book 2002 since 1987. The ONS provides values for residential buildings; agricultural assets; commercial, industrial, and other buildings; civil engineering works; plant and machinery; vehicles; and stocks and work in progress. Its average for 1990-2001 for total corporate tangible capital is 1.45 GDP. Note that the rise in corporate tangible capital is not negligible, as in the United States. The United Kingdom had larger increases in subsidies and a greater decline in corporate income tax rates than the United States. $^{30}$ However, the difference between the reproducible cost of tangible capital in the 1960s and the 1990s is only 0.22 GDP, much too small to account for the large increase in value shown in Figure 2.

We also report in Table 4 estimates of intangible capital. Unfortunately, the procedure that 
we use to estimate U.S. intangibles requires long and comparable time series for after-tax profits, tangible capital, growth rates, and depreciation rates. Consistent time series are not available for the United Kingdom.

We do, however, have direct measures on U.S. and U.K. research and development expenditures, which is a major component of intangible investment. ${ }^{31}$ We assume that R\&D capital is the same fixed fraction of intangible stock in the two countries and thus use the ratio of U.K. to U.S. investments in R\&D and our estimate of intangible investment to infer a value for U.K. total intangible investment. Assuming similar rates of accumulation, we can use the ratio of investments as our ratio of the intangible capital stocks.

The earliest year data are available for the United Kingdom is 1972, which we use for our estimate of U.K. intangible capital in the 1960s. In 1972, nondefense R\&D was 1.50 percent of GDP in the United Kingdom and 1.62 percent of GDP in the United States. Our estimate of intangible capital for the United States is 0.71 GDP. Thus, our estimate of intangible capital for the United Kingdom is $(0.71 \times$ U.S. GDP $)(1.5 \times$ U.K. GDP $) /(1.62 \times$ U.S. GDP $)$ or $0.66 \times$ U.K. GDP. Doing the same, for the later period, our estimate is $0.51 \times$ GDP.

To estimate the capital in foreign subsidiaries, we follow the same procedure that we used for the United States. The last row of Table 4 shows the ratio of foreign to domestic profits after tax. These ratios are derived from national accounts. ${ }^{32}$ We use these ratios as our estimate of the ratio of capital in foreign subsidiaries to capital at home.

The values in Table 4 are the elements we need to evaluate our key formula (30) for the value of U.K. corporations. In Table 5, we report the predictions along with the actual market values of corporate equities plus net debt. In order to allow for a direct comparison, we show the results for both countries. The main finding of the table is that changes in taxes account for most of the increase in corporate valuations that occurred between the 1960s and the end of the 20th century. The actual value of U.S. corporations increased by a factor of 1.66, and the model predicts an increase of 1.79. The actual value of U.K. corporations increased by a factor of 2.76 , and the model predicts an increase of 2.67. For both countries and both time periods, the model slightly underpredicts the level of the total value of corporations. But in all cases, the difference is less than 10 percent. Thus, the theory correctly predicts a larger increase in the value of corporations in the United Kingdom than in the United States. 
Table 5. Predicted and Actual U.S. and U.K. Corporate Values (Relative to GDP)

\begin{tabular}{|c|c|c|c|c|}
\hline & \multicolumn{2}{|c|}{ U.S. } & \multicolumn{2}{|c|}{ U.K. } \\
\hline & $1960-69$ & $1998-2001$ & 1960-69 & $1998-2001$ \\
\hline \multicolumn{5}{|l|}{ Predicted Fundamental Values } \\
\hline Domestic tangible capital & .563 & .838 & .572 & 1.320 \\
\hline Domestic intangible capital & .229 & .350 & .200 & .349 \\
\hline Foreign capital & .086 & .379 & .031 & .480 \\
\hline Total Relative to GDP & .877 & 1.567 & .802 & 2.148 \\
\hline \multicolumn{5}{|l|}{ ACtual Market Values } \\
\hline Corporate equities & .898 & 1.576 & .773 & 1.845 \\
\hline Net corporate debt & .041 & .028 & .019 & .375 \\
\hline Total Relative to GDP & .940 & 1.604 & .792 & 2.220 \\
\hline
\end{tabular}

\section{The low equity values in the $1970 \mathrm{~s}$}

Next we consider the effects of changes in tax policies on U.K. valuations in the 1970s. U.K. equity values were on average about 0.77 GDP in the 1960s and only 0.37 GDP in the second half of the 1970s. Some of this decline was offset by a rise in the value of net corporate debt. Using balance sheet data, which is reported for the first time by the ONS in its Blue Book 198\%, we estimate that net corporate debt averaged 0.089 GDP over the period 1975-79. This indicates a slight increase in the value of net debt relative to levels in the 1960s, but the total value of U.K. corporations still suffered a large decline, falling from an average of 0.808 in the 1960s to 0.459 in the second half of the 1970s.

An important change for the United Kingdom in this period is the increase in the rate of capital subsidies. Recall that expenditures on plant, machinery, and inventories were allowed immediate expensing during 1972-84, and by 1981, industrial buildings received an initial allowance of 75 percent, with writing down allowances in the period of expenditure. Thus, the United Kingdom was close to the extreme case with $\hat{\delta}_{1 x}=1$ in equation (29). In that case, the rate of the subsidy, $\tau_{\delta}$, is equal to the rate of the corporate income tax, $\tau_{1}$.

To see how important this policy is quantitatively, consider redoing the calculations of Table 5 for the United Kingdom in the 1960s, changing only the value of $\tau_{\delta}$ from 0 to 43.1 percent, which 
is the corporate income tax rate. Our prediction for the fundamental value of productive capital with the higher rate of investment subsidies would be 0.493 GDP. This is very close to the actual market value of 0.459 GDP that we calculated for the period 1975-79.

To get a more precise theoretical estimate, however, would require taking into account the expectations of corporations and shareholders and the interaction of changes of the tax system. In particular, for the U.K. case, we need to model expectations about the subsidies and their interaction with the dividend credit system, the advance corporation tax, and dividend controls that were in place between 1972 and 1979. (See Bond et al. (1996).)

In summary, we find that increased tax subsidies are a quantitatively important factor for the low U.K. equity values in the 1970s, accounting for almost all of the difference in corporate valuations between the 1960s and 1970s. The subsidies were greater in the United Kingdom than in the United States, which accounts for the fact that equity values were lower in the United Kingdom than the United States.

\section{The Long Transition in the 1980s and 1990s}

By the late 1980s, the major tax reforms that occurred in the United States and the United Kingdom had already been enacted. Not until the late 1990s did corporate equity values reach their peaks. (See Figure 2.) In this section, we use a version of the model of Section 2, with just tangible capital, to show that a long transition is to be expected in light of the constraints that U.S. and U.K. shareholders faced on their asset holdings in tax-deferred retirement accounts.

To demonstrate the consequences of tax-deferred savings plans for stock prices, we determine the equilibrium path if such a tax-deferred plan is adopted in the following economy. The fraction of total wage income that can be put into a tax-deferred retirement account is $\phi$. Shares $s_{r, t}$ in the retirement account evolve according to

$$
s_{r, t+1}=\max \left\{s_{r, t}+\left(d_{t} s_{r, t}+\phi w_{t}\right) / v_{t}, 1\right\}
$$

with $s_{r, 0}=0$, where $d_{t}$ is distributions per share, $v_{t}$ is the price per share, and $w_{t}$ is total wages. Equation (34) says that contributions to the tax-deferred account are maximal and no withdrawals are made until all equity is held in the tax-deferred account. Then no additional contributions are made and an amount equal to dividends is withdrawn. 
If there are no constraints on contributions to retirement accounts and all contributions are tax deductible, then the price of corporate equity would jump from $1-\tau_{\text {dist }}$ to 1 immediately, where $\tau_{d i s t}$ is the tax rate on corporate distributions. For simplicity we have assumed the same rate of tax on dividends and capital gains. If there are constraints, then the price of corporate capital would not jump to one immediately. To see this, first note that the difference equation governing the value of corporate capital is given by:

$$
\begin{aligned}
& v_{t}=\left(1-\tau_{\text {dist }}\right) k_{t+1}, \text { for } 1 \leq t<t_{1}^{*} \\
& v_{t}=\left(1+\frac{i}{1-\tau_{\text {dist }}}\right) v_{t-1}-d_{t}, \text { for } t_{1}^{*} \leq t \leq t_{2}^{*} \\
& v_{t}=k_{t+1}, \text { for } t>t_{2}^{*} .
\end{aligned}
$$

Dividends are equal to $d_{t}=(i-g) k_{t}$, where $i$ is the real interest rate and $g$ is the growth rate of the economy. Equation (36) is required for an individual to be indifferent between selling a share today and selling it tomorrow.

The difference equations governing the evolution of shares held in the tax-deferred retirement account $s_{r}$ and the value of corporate capital $v$ are (34)-(36). The boundary conditions are that $s_{r}$ is zero in period 0 , less than one for $t<t_{2}^{*}$, and one for $t \geq t_{2}^{*}$. Net contributions in $t_{2}^{*}$ are such that the tax-deferred account purchases all of the remaining stocks in nonretirement accounts. The value of $v / k$ either starts out at a number exceeding $\left(1-\tau_{\text {dist }}\right)$ or is $\left(1-\tau_{\text {dist }}\right)$ for some time interval of length $t_{1}^{*}$. Then it obeys (36) until $v / k=1$. Expectations of when the policy will be implemented matter only if contributions are sufficiently large.

Consider the following parameterization of the model economy. The time period is one year. The aggregate production function is Cobb-Douglas with the labor share equal to 0.68. The aggregate capital stock is 3.0 GDP; here, we have only one sector. The rate of interest is 4.1 percent, and the economy grows at a rate of 3 percent. The tax rate on distributions is 42 percent. Investors are allowed to put 10 percent of their wages into the retirement account starting at time period 0 .

Figure 3 plots the model's equilibrium adjustment path for the price of capital $q=v / k$. As the figure shows, that path is long, nearly 25 years. There is also an initial 4-year period in which the price stays at $1-\tau_{\text {dist }}$. 
Figure 3. The Adjustment Path for the Price of Capital

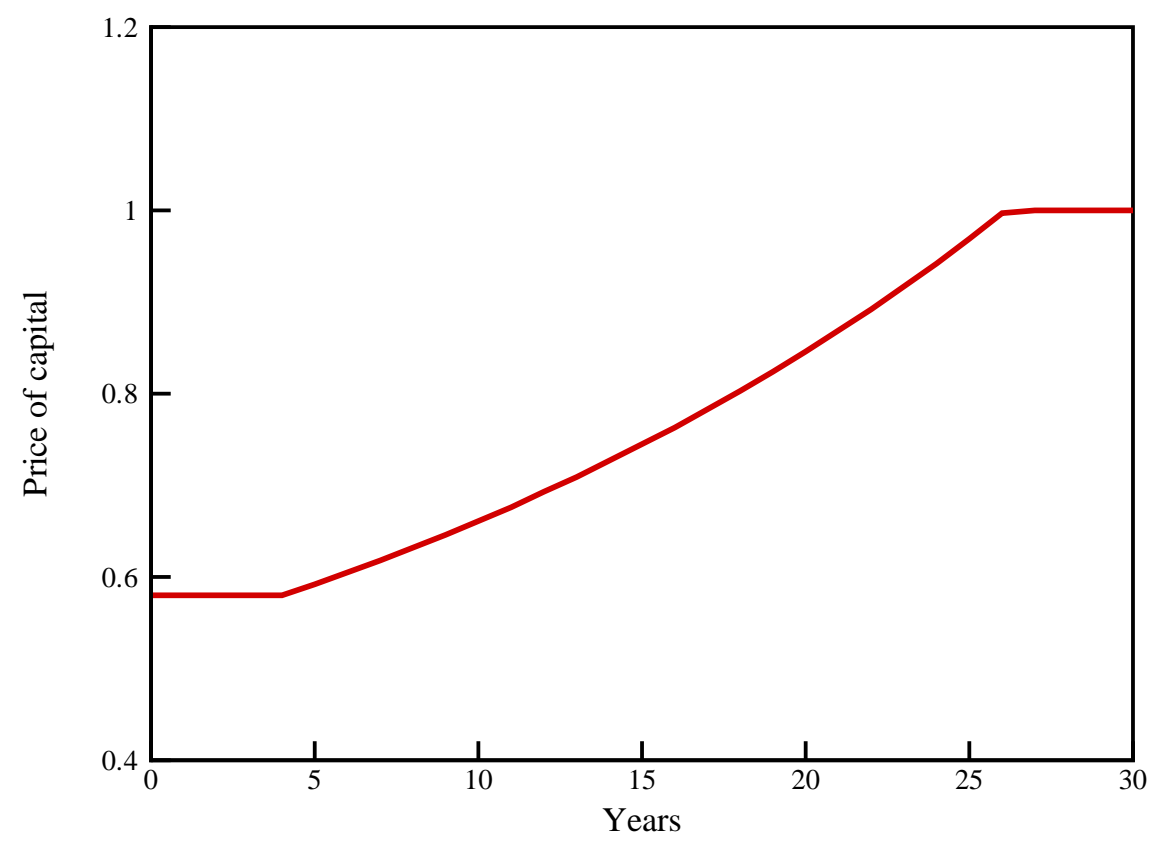

A well-calibrated overlapping generations model is needed to be more precise about the actual length of the adjustment path. (See Quadrini and Rios-Rull, 1997, for a recent survey of the literature. ${ }^{33}$ ) However, this example does establish that the adjustment path will be long. This is consistent with the behavior of both U.S. and U.K. equity prices from the early 1980s to the late 1990s, when tax laws favored tax-deferred retirement accounts and participation in those plans increased dramatically.

\section{Summary}

Here we have derived the prediction of growth theory - the standard tool of macroeconomics and public finance - for the value of U.S. and U.K. corporations in the period 1960-2001. Given the changes in tax and regulatory policy during this period, the theory predicts that both countries should have experienced dramatic declines in corporate valuations in the 1970s and dramatic increases starting in the 1980s and continuing through the 1990s. Both did. We also find that predicted and actual valuations are close in magnitude, indicating that the tax system is a quantitatively important factor for the large, secular movements we observed.

The approach we have taken in this paper uses national account statistics along with tax and 
regulatory information to estimate the equilibrium price of corporate equity. The growth model was developed to account for the secular movements in these statistics. For the period we consider, the large secular movements in the value of the stock market relative to gross national income are accounted for by the theory.

A puzzle that is as yet unsolved is the higher-frequency volatility in the stock market, which is unlikely to be the result of persistent changes in tax rates and regulations. Time-varying discount rates can induce a large variation in prices for relatively smooth sequences of dividends. However, values of corporate capital stocks do not vary enough to justify the enormous variation in stock prices. Since the value of capital is itself equal to the discounted stream of dividends, adding stochastic discount rates only leads to counterfactual predictions for the value of the capital stock. Thus, the challenge for macroeconomists and financial economists is to find theories consistent with the data on macro aggregates, like capital stocks, and the data on financial aggregates, like the market value of corporate equities. We hope and expect that integrating the stock market into the growth model will lead to a better understanding of both aggregate quantities and prices.

We have focused on a dynastic economy and predictions of theory for the various tax regimes in place in the United States and the United Kingdom during the post-World War II period. We have established that changes in tax policy have been important for corporate valuations in both countries. However, our framework is poorly suited for modeling the transition period following a major tax reform. A well-calibrated overlapping generations model, one that matches micro observations on household behavior, is needed to determine the quantitative nature of the equilibrium path during transitions.

Allowing for heterogeneous individuals will also help quantify the effects of increased market participation and diversification that has occurred in the past two decades. Until very recently, mutual funds were a very expensive method of creating a diversified equity portfolio. Abstracting from diversification costs has only a modest effect on the total value of corporations, but could have a more important effect on estimates of the equity returns of mutual fund shareholders. Our work in McGrattan and Prescott (2003a) suggests that these effects are large. 


\section{Appendix A. Primary Data Sources}

A detailed data appendix is available at our website (http://minneapolisfed.org). In this appendix we provide a brief overview of our primary data sources.

- Figure 1. Federal Reserve Board of Governors (1945-2002).

- Figure 2. Federal Reserve Board of Governors (1945-2002), Stone et al. (1966), Revell (1967), Moyle (1971), Roe (1971), U.K. Central Statistical Office (CSO) (1979), Stock Exchange (1982), U.K. Office for National Statistics (ONS) Share Ownership (1994, 1997-2002), London Stock Exchange (2002), ONS Blue Book 2002, and ONS Pink Book 2002.

- Table 1. U.S. Department of Commerce (1929-2002), U.S. Department of the Treasury (19552000), Federal Reserve Board of Governors (1945-2002), Feenberg and Coutts (1993), and the Investment Company Institute (2003).

- Table 2. U.S. Department of Commerce (1929-2002), Federal Reserve Board of Governors (1945-2002).

- Table 3. Same sources as Tables 1 and 2.

- Tables 4 and 5. U.S. sources are same as in Tables 1-3. U.K. sources are those listed for Figure 2 as well as U.K. Central Statistical Office (CSO) (1971), Poterba and Summers (1984), King and Fullerton (1984), National Science Foundation (1953-2002), U.K. Inland Revenue Statistics and Economics Office (1970-2002). 


\section{Appendix B. Proofs of Propositions 3 and 4}

Here we prove Proposition 3, which expresses the total value of corporate equity in equation (27), and Proposition 4, which is the total value in (28) for the case when the economy is on a balancedgrowth path.

Proof: Use (15)-(17) to replace $y_{1, t}, x_{1 m, t}$ and $x_{1 u, t}$, respectively, in the corporate firm's problem. The maximization problem then is to maximize (24) subject to

$$
(1+\eta)(1+\pi) \hat{k}_{1 m, t+1}=\left(1-\hat{\delta}_{1 m}\right) \hat{k}_{1 m, t}+\left(1-\hat{\delta}_{1 x}\right)\left[(1+\eta) k_{1 m, t+1}-\left(1-\delta_{1 m}\right) k_{1 m, t}\right] .
$$

The first-order conditions for the firm with respect to $k_{1 m, t+1}, \hat{k}_{1 m, t+1}$, and $k_{1 u, t+1}$ are that

$$
\begin{aligned}
(1+\eta) \frac{p_{t}}{p_{t+1}}= & {\left[\left(1-\tau_{1}\right)\left(p_{1, t+1} f_{1, t+1}^{c}-\tau_{1 k}\right)+\left(1-\delta_{1 m}\right)\left(1-\tau_{x}-\tau_{1} \hat{\delta}_{1 x}-\left(1-\hat{\delta}_{1 x}\right) \lambda_{t+1}\right)\right] } \\
& /\left[1-\tau_{x}-\tau_{1} \hat{\delta}_{1 x}-\left(1-\hat{\delta}_{1 x}\right) \lambda_{t}\right] \\
(1+\eta) \frac{p_{t}}{p_{t+1}}= & {\left[\lambda_{t+1}\left(1-\hat{\delta}_{1 m}\right)+\tau_{1} \hat{\delta}_{1 m}\right] /\left[\lambda_{t}(1+\pi)\right] } \\
(1+\eta) \frac{p_{t}}{p_{t+1}}= & p_{1, t+1} f_{2, t+1}^{c}+1-\delta_{1 u}
\end{aligned}
$$

where $\lambda_{t}$ is the multiplier on (B1) normalized by $p_{t}$ and $f_{j, t}^{c}$ is the partial derivative of the corporate production function with respect to its $j$ th argument.

From the household's problem, we derive that

$$
\frac{p_{t}}{p_{t+1}}=\frac{v_{1 s, t+1}+\left(1-\tau_{d}\right) d_{1, t+1}}{v_{1 s, t}}
$$

which relates the inverse of the marginal rate of substitution to the gross return on equity.

Multiply (B2) by $\left(1-\tau_{x}-\tau_{1} \hat{\delta}_{1 x}-\left(1-\hat{\delta}_{1 x}\right) \lambda_{t}\right) k_{1 m, t+1}$, (B3) by $\lambda_{t}(1+\pi) \hat{k}_{1 m, t+1}$, and (B4) by $\left(1-\tau_{1}\right) k_{1 u, t+1}$; sum up terms, and multiply both sides by $1-\tau_{d}$. The resulting equation is consistent with (B5) if and only if

$$
\begin{aligned}
v_{1 s, t}=\left(1-\tau_{d}\right)(1+\eta)\left[\left(1-\tau_{x}\right.\right. & \left.-\tau_{1} \hat{\delta}_{1 x}-\left(1-\hat{\delta}_{1 x}\right) \lambda_{t}\right) k_{1 m, t+1} \\
& \left.+\lambda_{t}(1+\pi) \hat{k}_{1 m, t+1}+\left(1-\tau_{1}\right) k_{1 u, t+1}\right] .
\end{aligned}
$$


We now show that on a balanced-growth path,

$$
\left(1-\tau_{x}-\tau_{1} \hat{\delta}_{1 x}-\left(1-\hat{\delta}_{1 x}\right) \lambda\right) k_{1 m, t+1}+\lambda(1+\pi) \hat{k}_{1 m, t+1}=\left(1-\tau_{x}-\tau_{\delta}\right) k_{1 m, t+1}
$$

where $\tau_{\delta}$ is defined as follows:

$$
\tau_{\delta}=\tau_{1} \hat{\delta}_{1 x}+\left(1-\hat{\delta}_{1 x}\right) \lambda\left[1-(1+\pi) \frac{(1+\eta)(1+\gamma)-1+\delta_{1 m}}{(1+\eta)(1+\gamma)(1+\pi)-1+\hat{\delta}_{1 m}}\right]
$$

On a balanced-growth path, the real interest rate is equal to $(1+\eta) p_{t} / p_{t+1}-1$. Using (B3), we have that

$$
\lambda=\frac{\tau_{1} \hat{\delta}_{1 m}}{(1+i)(1+\pi)-1+\hat{\delta}_{1 m}} .
$$

Using (B1), we have that

$$
\hat{k}_{1 m, t+1}=\left(\frac{\left[(1+\eta)(1+\gamma)-1+\delta_{1 m}\right]\left(1-\hat{\delta}_{1 x}\right)}{(1+\eta)(1+\gamma)(1+\pi)-1+\hat{\delta}_{1 m}}\right) k_{1 m, t+1} .
$$

Substituting (B9) and (B10) into the left side of (B7) gives the expression (29) for $\tau_{\delta}$. Substituting (B7) into (B6) gives the expression (28) for the equity price. 


\section{Notes}

${ }^{1}$ Primary data sources are provided in Appendix A. A detailed description of the data used in this study is available in McGrattan and Prescott (2003b).

${ }^{2}$ This phrase was used by Federal Reserve Chairman Alan Greenspan (1996).

${ }^{3}$ An early dynamic general equilibrium model with corporate equity prices is Lucas and Prescott's (1971). Hayashi (1982) extends and applies their structure.

${ }^{4}$ It turns out that the large run-up in equity values was not due to a change in financing decisions. In both the 1960s and the 1990s, net corporate debt was low relative to equity.

${ }^{5}$ Here we abstract from all forms of heterogeneity in individuals. We view this as a first step toward understanding the interaction of stock values and the U.S. tax system. Obvious extensions would allow for individuals of different ages, incomes, and abilities. See, for example, Alvarez and Jermann (2001) and Constantinides et al. (2002).

${ }^{6}$ Because of our emphasis on taxation as a key factor for postwar asset prices, we analyze a production economy. See also the work of Donaldson and Mehra (1984), Rouwenhorst (1995), Jermann (1998), and Hall (2001), who study asset pricing in production economies.

${ }^{7}$ See, for example, King (1977), Summers (1981), Auerbach (1983a, 2002), and Poterba (2002). There are two alternative views in the finance literature which imply that the value of corporate equity is equal to the reproducible cost of capital. See Poterba and Summers (1985) for a clear exposition of these views.

${ }^{8}$ Clearly, the formula would not hold in the Great Depression when the investment corners were so important.

${ }^{9}$ Sinn (1991) shows that through mergers a firm with good investment opportunities can merge with one that has a big cash flow but few investment opportunities, thereby avoiding the need to issue new equity. New equity issue is a more costly way of financing investment than through retained earnings.

${ }^{10} \mathrm{~A}$ perceptive referee pointed out that this result is just Ricardian equivalence in disguise.

${ }^{11}$ Here pension funds include annuities provided by life insurance companies.

${ }^{12}$ Buybacks were of greater importance in 1972 and 1973, but this is because a ceiling on dividends had been imposed during Nixon's Economic Stabilization Program.

${ }^{13}$ For example, only one broker or dealer can be employed on any day to buy stocks; the corporation cannot perform the opening trade or trade during 30 minutes prior to market close; the buybacks cannot exceed a specific volume; and the corporation cannot reacquire its stock at a price or bid exceeding the highest independent bid.

${ }^{14}$ Elton and Gruber (1970) propose an alternative method for estimating the tax rate on distributions that involves comparing cum- and ex-dividend stock prices. To apply this method, we would need to introduce heterogeneity, and we would have to address Boyd and Jagannathan's (1994) concern that there is a large noise-to-signal ratio in econometric procedures using ex-dividend reports.

${ }^{15}$ In the 1986 TRA, this average was increased by a factor of 1.4. See King and Fullerton (1984), Tables 6-5 and 6-29, and Fullerton and Karayannis (1993), Table 10-7.

${ }^{16}$ Our corporate sector includes both publicly traded and privately held corporations. See Moskowitz and Vissing-Jorgensen (2002) for a comparison of publicly and nonpublicly traded companies.

${ }^{17}$ Because quantities in the budget constraint are in per-capita terms, $p_{t}$ is the intertemporal household price of consumption multiplied by the population in $t$. The rate of interest between $t$ and $t+1$ is therefore given by $\left(p_{t} / N_{t}\right) /\left(p_{t+1} / N_{t+1}\right)-1$ or $(1+\eta) p_{t} / p_{t+1}-1$.

${ }^{18}$ For this comparison, we assume that book capital and market capital are close in value and set $\tau_{\delta}$ equal to zero. In our analysis of the 1970s, we assume that sustained inflation and generous depreciation allowances led to a significant increase in $\tau_{\delta}$. 
${ }^{19}$ In McGrattan and Prescott $(2000,2001)$ we use returns from the noncorporate sector as our measure of $i$ and find similar results. Two difficult choices must be made when computing noncorporate returns: (1) how to allocate net interest to final and intermediate product; and (2) how to allocate proprietor's income to capital and labor. Using growth rates and discount factors here, we avoid having to make these choices.

${ }^{20}$ The investment figures are taken from Table F6. We sum across all corporate categories and assume that 10 percent of farm business is corporate.

${ }^{21}$ Some estimates in the literature assume that the difference between stock values and tangible capital stock values is the value of intangible capital. See, for example, Hall (2001). We do not want to assume a priori that the large run-up in equity values is due to a rise in the value of intangibles.

${ }^{22}$ As we show later, the transition period following the 1986 TRA was slow. For this reason, we compare the model predictions to averages for the period 1998-2001, when prices reached a higher plateau.

${ }^{23}$ The value of net debt is the average of corporate debt liabilities less debt assets from the Federal Reserve's Flow of Funds Accounts multiplied by one less the tax rate on distributions. We make an adjustment for taxes on distributions since companies can adjust capital and debt one for one before making distributions. Also, following Hall (2001) we make an adjustment to the book values from the Flow of Funds Accounts so as to get market values of debt.

${ }^{24}$ If accounting profits do not reflect economic profits, we would not correctly infer the level of foreign capital. Suppose, for example, a company uses transfer pricing to shift profits to its subsidiary in a country with low corporate tax rates and shift costs to the parent in the United States. Fortunately, most foreign investment is done in countries with similar tax provisions to those in the United States.

${ }^{25}$ Baxter and Jermann (1997) find that individuals are not well diversified internationally. But significant diversification occurs through capital holdings of foreign subsidiaries.

${ }^{26}$ If $\pi=0$, our estimate of $\tau_{\delta}$ would be 0.19 . Thus, we find that $\tau_{\delta}$ is not necessarily increasing in $\pi$, and the effects are much smaller than Feldstein (1980) estimates.

${ }^{27}$ This is consistent with Auerbach's (1983b) estimates of approximately 20 percent for the investment subsidies in the late 1970s and early 1980s. See his Table 12.

${ }^{28}$ See Appendix A for primary sources and McGrattan and Prescott (2003b) for more details. The equity values shown in Figure 2 are net of intercorporate holdings and relative to GDP. We plot equity values rather than total corporate values in Figure 2 because we do not have comparable net debt values for all years for the United Kingdom.

${ }^{29}$ We include only subsectors of nonfinancial companies and financial institutions that issue U.K. quoted or unquoted ordinary shares.

${ }^{30}$ Another reason for higher capital stocks in the United Kingdom across time is coverage: ONS includes unincorporated enterprises while Roe (1971) does not.

${ }^{31}$ The estimates in Table 4 for the United Kingdom are based on data of the National Science Foundation (1953-2002). The NSF reports nondefense R\&D expenditures as a percentage of national GDP.

${ }^{32}$ The United Kingdom has recently revised its accounting methods to be consistent with European standards. We use the earlier ONS Blue Book 1997, which provides details we need on trading profits. See McGrattan and Prescott (2003b) for more details.

${ }^{33}$ With an overlapping generations model, initially retirees will be selling more shares than are being bought by the retirement accounts, and some people near retirement will be buying shares for their personal account. At some point, the sales of old people will be equal to the purchases of the retirement accounts, and then the price of corporate capital will be one. At a price of one, there will be some workers on the margin between contributing a little more and a little less to their retirement accounts and some retired people on the margin between selling and buying a few more shares. 


\section{References}

ABEL, A. B. (2003), "The Effects of a Baby Boom on Stock Prices and Capital Accumulation in the Presence of Social Security", Econometrica, 71, 551-578.

ALVAREZ, F. and JERMANN, U. (2001), "Quantitative Asset Pricing Implications of Endogenous Solvency Constraints", Review of Financial Studies, 14, 1117-1151.

ARROW, K. J. (1962), "The Economic Implications of Learning by Doing", Review of Economic Studies, 29, 155-173.

AUERBACH, A. J. (1983a), "Taxation, Corporate Financial Policy and the Cost of Capital", Journal of Economic Literature, 21, 905-940.

AUERBACH, A. J. (1983b), "Corporate Taxation in the United States", Brookings Papers on Economic Activity, 2, 451-505.

AUERBACH, A. J. (2002), "Taxation and Corporate Financial Policy", in A. J. Auerbach and M. S. Feldstein (eds.), Handbook of Public Economics, Volume 3 (New York: Elsevier NorthHolland), 1251-1292.

BAXTER, M. and JERMANN, U. (1997), "The International Diversification Puzzle Is Worse Than You Think", American Economic Review, 87, 170-180.

BITTKER, B. I. and Eustice, J. S. (2000), Federal Income Taxation of Corporations and Shareholders, 7th edition (Valhalla, N.Y.: Warren, Gorham, and Lamont).

BOND, S., CHENNELLS, L. and DEVEREUX, M. (1996), "Company Dividends and Taxes in the UK", Fiscal Studies, 16, 1-18.

BOYD, J. H. and JAGANNATHAN, R. (1994), "Ex-Dividend Price Behavior of Common Stocks", The Review of Financial Studies 7, 711-741.

CAMPBELL, J. Y. and SHILLER, R. J. (2001), "Valuation Ratios and the Long-Run Stock Market Outlook: An Update" (Working paper 8221, NBER).

CONSTANTINIDES, G. M., DONALDSON, J. B., and MEHRA, R. (2002), "Junior Can't Borrow: A New Perspective of the Equity Premium Puzzle", Quarterly Journal of Economics, 117, 269-296.

CORRAdO C., HULTEN, C. R., and SICHEL, D. E. (2005), "Measuring Capital and Technology: An Expanded Framework", in C. Corrado, J. Haltiwanger, and D. Sichel (eds.), Measuring Capital in the New Economy (Chicago: University of Chicago Press).

DONALDSON, J. B. and MEHRA, R. (1984), "Comparative Dynamics of an Equilibrium Intertem- 
poral Asset Pricing Model", Review of Economic Studies, 51, 491-508.

ELTON, E. J. and GRUBER, M. J. (1970), "Marginal Stockholder Tax Rates and the Clientele Effect", The Review of Economics and Statistics, 52, 68-74.

FEDERAL RESERVE BOARD OF GOVERNORS (1945-2002), Flow of Funds Accounts of the United States (Washington, D.C.: Federal Reserve Board).

FEENBERG, D. R. and COUTTS, E. (1993), "An Introduction to the TAXSIM Model", Journal of Policy Analysis and Management, 12, 189-194.

FELDSTEIN, M. (1980), "Inflation and the Stock Market" American Economic Review, 70, 839847.

FULLERTON, D. and KARAYANNIS, M. (1993), "United States", in D. W. Jorgenson and R. Landau (eds.), Tax Reform and the Cost of Capital, Chapter 10 (Washington, D.C.: Brookings Institution), 333-367.

GREENSPAN A. (1996), "The Challenge of Central Banking in a Democratic Society", Francis Boyer Lecture of American Enterprise Institute for Public Policy Research, December 5 (Washington, D.C.: Federal Reserve Board).

GREENWOOD, J. and JOVANOVIC, B. (1999), "The Information-Technology Revolution and the Stock Market", American Economic Review, 89, 116-122.

GRULLON, G. and MICHAELY, R. (2002), "Dividends, Share Repurchases, and the Substitution Hypothesis", Journal of Finance, 57, 1649-1684.

HALL, R. E. (2001), "The Stock Market and Capital Accumulation", American Economic Review, 91, 1185-1202.

HAYASHI, F. (1982), "Tobin's Marginal q and Average q: A Neoclassical Interpretation", Econometrica, 50, 213-224.

HEATON, J. and LUCAS, D. (1999), "Stock Prices and Fundamentals", in O. J. Blanchard and S. Fisher (eds.), NBER Macroeconomics Annual 1999 (Cambridge, Mass.: MIT Press), $213-242$.

HILL, I. and TAYLOR, R. (2001), "Recent Trends in Dividends Payments and Share Buy-Backs", Economic Trends, February (London: The Stationery Office), 567, 42-44.

HOBIJN, B. and JOVANOVIC, B. (2001), "The Information-Technology Revolution and the Stock Market: Evidence", American Economic Review, 91, 1203-1220.

INVESTMENT COMPANY INSTITUTE (2003), "Mutual Funds and the U.S. Retirement Market in 2002", Fundamentals, 12, 1-15. 
IRWIN, D. and KLENOW, P. J. (1994), "Learning-by-Doing Spillovers in the Semiconductor Industry", Journal of Political Economy, 102, 1200-1227.

JERMANN, U. J. (1998), "Asset Pricing in Production Economies", Journal of Monetary Economics, 41, 257-275.

KING, M. A. (1977), Public Policy and the Corporation (London, U.K.: Chapman and Hall).

KING, M. A. and FULLERTON, D., eds. (1984), The Taxation of Income from Capital: A Comparative Study of the United States, the United Kingdom, Sweden, and West Germany (Chicago: University of Chicago Press).

KING, M. A. and ROBSON, M. H. (1993), "United Kingdom", in D. W. Jorgenson and R. Landau (eds.), Tax Reform and the Cost of Capital, Chapter 9 (Washington, D.C.: Brookings Institution), 300-332.

LAITNER, J. and STOLYAROV, D. (2003), "Technological Change and the Stock Market", American Economic Review, 93, 1240-1267.

LONDON STOCK EXCHANGE (2002), Historical Statistics, http://www.londonstockexchange. com/market/historic.asp.

LUCAS, R. E., Jr. and PRESCOTT, E. C. (1971), "Investment Under Uncertainty", Econometrica, 39, 659-681.

MCGRATTAN, E. R. and PRESCOTT, E. C. (2000), "Is the Stock Market Overvalued?" Federal Reserve Bank of Minneapolis Quarterly Review, 24(Fall), 20-40.

MCGRATtAN, E. R. and PRESCOTT, E. C. (2001), "Taxes, Regulations, and Asset Prices" (Working Paper 610, Federal Reserve Bank of Minneapolis).

MCGRATTAN, E. R. and PRESCOTT, E. C. (2003a), "Average Debt and Equity Returns: Puzzling?" American Economic Review, 93, 392-397.

MCGRATtAN, E. R. and PRESCOTt, E. C. (2003b), "Data Appendix: Taxes, Regulations, and the Value of U.S. and U.K. Corporations" (Staff Report 309, Federal Reserve Bank of Minneapolis).

MOSKOWITZ, T. J. and VISSING-JORGENSEN, A. (2002), "The Returns to Entrepreneurial Investment: A Private Equity Premium Puzzle", American Economic Review, 92, 745-778.

MOYLE, J. (1971), "The Pattern of Ordinary Share Ownership", Department of Applied Economics, Occasional Paper 31 (Cambridge, U.K.: Cambridge University Press).

NATIONAL SCIENCE FOUNDATION (1953-2002), National Patterns of REDD Resources (Washington, D.C.: National Science Foundation). 
PERALTA-ALVA, A. (2003), "Technical Change and U.S. Stock Market Movements" (Ph.D. diss., University of Minnesota).

POTERBA, J. M. (2002), "Taxation, Risk-taking, and Household Portfolio Behavior", in A. J. Auerbach and M. S. Feldstein (eds.), Handbook of Public Economics, Volume 3 (New York: Elsevier North-Holland), 1109-1171.

POTERBA, J. M. and SUMMERS, L. H. (1984), "New Evidence That Taxes Affect the Valuation of Dividends", Journal of Finance, 39, 1297-1415.

POTERBA, J. M. and SUMMERS, L. H. (1985), "The Economic Effects of Dividend Taxation", in E. I. Altman and M. G. Subrahmanyam (eds.), Recent Advances in Corporate Finance (Homewood, Ill.: Irwin), 227-284.

PRESCOTT, E. C. and VISSCHER, M. (1980), "Organization Capital”, Journal of Political Economy, 88, 446-461.

QUADRINI, V. and RIOS-RULL, J-V. (1997), "Understanding the U.S. Distribution of Wealth", Federal Reserve Bank of Minneapolis Quarterly Review, 21(Spring), 22-36.

REVELL, J. (1967), The Wealth of the Nation: The National Balance Sheet of the United Kingdom, 1957-1961, Department of Applied Economics, Monograph 14 (Cambridge, U.K.: Cambridge University).

ROE, A. (1971), The Financial Interdependence of the Economy (London: Chapman and Hall).

ROUWENHORST, K. G. (1995), "Asset Pricing Implications of Equilibrium Business Cycle Models", in T. F. Cooley (ed.), Frontiers of Business Cycle Research (Princeton, N.J.: Princeton University Press), 294-330.

SHILLER, R. J. (2000), Irrational Exuberance (Princeton, N.J.: Princeton University Press).

SHIRLEY, P. (1997), "Share Repurchases", Fiscal Studies, 18, 211-221.

SINN, H-W. (1991), "Taxation and the Cost of Capital: The 'Old' View, the 'New' View, and Another View", in D. Bradford (ed.), Tax Policy and the Economy, Volume 5 (Cambridge, Mass.: MIT Press), 25-54.

STOCK EXCHANGE (1982), The Stock Exchange Survey of Share Ownership (London: Stock Exchange Publications).

STONE, R., REVELL, J. and MOYLE, J. (1966), The Owners of Quoted Ordinary Shares: A Survey for 1963 (London: Chapman and Hall).

SUMMERS, L. H. (1981), "Taxation and Corporate Investment: A q-Theory Approach", Brookings Papers on Economic Activity, 1, 67-127. 
U.K. CENTRAL STATISTICAL OFFICE (1971), National Income and Expenditure (London: Her Majesty's Stationery Office).

U.K. CENTRAL STATISTICAL OFFICE (1979), The Owners of Quoted Ordinary Shares: A Survey for 1975 (London: Her Majesty's Stationery Office).

U.K. INLAND REVENUE STATISTICS AND ECONOMICS OFFICE (1970-2002), Inland Revenue Statistics (London: Her Majesty's Stationery Office).

U.K. OFFICE FOR NATIONAL STATISTICS (1987, 1997, 2002), United Kingdom National Accounts, The Blue Book (London: The Stationery Office).

U.K. OFFICE FOR NATIONAL STATISTICS (2002), United Kingdom Balance of Payments, The Pink Book (London: The Stationery Office).

U.K. OFFICE FOR NATIONAL STATISTICS (1994, 1997-2002), Share Ownership: A Report on the Ownership of Shares at 31st of December (London: The Stationery Office).

U.S. DEPARTMENT OF COMMERCE, Bureau of Economic Analysis (1929-2002), Survey of Current Business (Washington, D.C.: U.S. Government Printing Office).

U.S. DEPARTMENT OF THE TREAURY, Internal Revenue Service (1955-2000), Statistics of Income (Washington, D.C.: U.S. Government Printing Office).

UNIVERSAL MCCANN (1929-2000), Bob Coen's Insider's Report (New York: McCann-Erickson World Group). 